\title{
Bimetallic Fe/Al-MOF for the Adsorptive Removal of Multiple Dyes: Optimization and Modeling of Batch and Hybrid Adsorbent-river Sand Column Study
}

Hemant Singh

IIT Kharagpur: Indian Institute of Technology Kharagpur

\section{Sankalp Raj}

IIT Kharagpur: Indian Institute of Technology Kharagpur

Rishi karan singh rathour

IIT Kharagpur: Indian Institute of Technology Kharagpur

Jayanta Bhattacharya ( $\sim$ jayantaism@gmail.com )

Indian Institute of Technology Kharagpur https://orcid.org/0000-0001-8644-2915

\section{Research Article}

Keywords: Bimetallic Metal-Organic Framework, Adsorption modelling, hybrid sand-adsorbent, Fixed-bed column, Dyes adsorption, Rhodamine B adsorption

Posted Date: December 22nd, 2021

DOI: https://doi.org/10.21203/rs.3.rs-1128193/v1

License: (9) This work is licensed under a Creative Commons Attribution 4.0 International License. Read Full License 
Bimetallic Fe/Al-MOF for the adsorptive removal of multiple dyes: Optimization and

2

3 modeling of batch and hybrid adsorbent-river sand column study

Hemant Singh a , Sankalp Raj a , Rishi Karan Singh Rathour ${ }^{\text {a,b }}$, Jayanta Bhattacharya ${ }^{\text {a, c, d *, }}$

${ }^{\text {a }}$ School of Environmental Science and Engineering, Indian Institute of Technology

Kharagpur, India

b IPE Global Limited, New Delhi, India

${ }^{c}$ Department of Mining Engineering Indian Institute of Technology Kharagpur, India

${ }^{d}$ Zelence Industries Pvt. Ltd., India 
Abstract

Bimetallic Metal organic framework (MOF) has garnered interest over the years with its application in various environmental remediation. In this study, Fe-Al-1,4-Benzene diCarboxylic acid (FeAl(BDC)) MOF was synthesized, and adsorptive removal of Rhodamine $\mathrm{B}$ dye in batch and unique hybrid FeAl (BDC)-River sand fixed-bed column was achieved. The experimental data from the batch studies corroborated well with the Pseudo second-order (PSO) and Freundlich adsorption isotherm models. Furthermore, a fixed-bed column study was conducted to assess the effect of varying flow rate $(2,5,8 \mathrm{~mL} / \mathrm{min})$, bed height $(5,9,13$ $\mathrm{cm}$ ), and feed concentration $(10,20,30 \mathrm{mg} / \mathrm{L})$ on the adsorption performance of $\mathrm{FeAl}(\mathrm{BDC})$ in continuous mode of operation. A uniform mixture of river sand and $\mathrm{FeAl}(\mathrm{BDC})$ by weight ratio (9:1) was achieved prior to packing the column. The column study reveals that Sand$\mathrm{FeAl}(\mathrm{BDC})$ can achieve the maximum adsorption capacity of $113.05 \mathrm{mg} / \mathrm{g}$ at a flow rate of 5 $\mathrm{mL} / \mathrm{min}$, feed concentration of $20 \mathrm{mg} / \mathrm{L}$, and bed height of $13 \mathrm{~cm}$. The experimental data of the column study were successfully fitted with BDST, Thomas, Yoon-Nelson, and Doseresponse models. The fitting parameter values from the BDST model raise the scope of possible upscaling of the fixed-bed column. Hence, it is proposed that these River sand$\mathrm{FeAl}(\mathrm{BDC})$-based filters can be widely used in areas facing critical contamination and in poor communities with a high demand for water.

Keywords: Bimetallic Metal-Organic Framework; Adsorption modelling; hybrid sandadsorbent; Fixed-bed column; Dyes adsorption; Rhodamine B adsorption

\section{Introduction}

Synthetic dyes are ubiquitous for their use as colouring compounds in textiles, food processing, leather accessories, paper and plastics, cosmetic, printing, and cell staining agents 
in biological studies (Amini et al. 2011; Yadav and Tyagi 2011; Charumathi and Das 2012). Large portions of these dyes, after use and application, are finally drained to various water bodies and remain there as persistent pollutants and toxicants. They cause multiple irreversibly detrimental effects on the aquatic life by introducing various toxicity; their suspension in water restricts sunlight entry and thus photosynthesis process, and lead to disruption of food chain also influencing human health. Though largely unknown to the current science many of such dyes are known carcinogenic, non-biodegradable in nature, and initially cause discomfort and irritation to skins and eyes, and when inhaled, severe discomfort in the respiratory tract (Charumathi and Das 2012; Nagaraja et al. 2012; Tiwari et al. 2015; Lellis et al. 2019; Geetha Malini et al. 2020). They pose severe challenges to conventional public water treatment systems as they can escape standard treatment schemes. The presence of these dyes in water bodies is a well recognized nuisance and problematic to the aesthetics (Aksu and Tezer 2005; Gupta and Suhas 2009). Many of them are highly stable and can resist biological degradation over a long time. A study estimates almost 10-15\% of unused dyes are released as effluents, and many find ways to water systems from the disposed substances (Kiran et al. 2006; Saini 2017). The organic dye used for the detailed experiments is Rhodamine B. It is a well-known cationic fluorescent, highly water-soluble xanthene dye. It is one of the most predominantly used dyes and has found its application in a variety of research and industrial fields. But due to its high stability, it may also end up as a pollutant in the natural environment (Richardson et al. 2004; Lu et al. 2012; Nagaraja et al. 2012).

Several biological, physical, and chemical techniques for dye removal from water have been in use. Out of all these, the predominant techniques are adsorption and catalysis. Adsorption is advantageous over catalysis, as the pollutants are transferred between two phases rather than producing unfavorable degradation byproducts (Chegeni et al. 2021). Many other methods have not been popular because of the high cost involved, and lack of feasibility and reliability as well as new environmental impacts, difficulty in using and disposing them. There is relentless research for developing efficient materials for dye removal by adsorption (Robinson et al. 2001; Chen and Chen 2009).

Metal organic framework (MOF) is a combination of nodes and linkers, inorganic (metal ions or clusters/SBUs (Structure building units)) and organic in nature. Such materials belong to a class of coordination polymers (Yaghi et al. 2003). Metal organic frameworks are a wellknown class of crystalline and porous 2D,3D structures formed with nodes and organic bridges (Gangu et al. 2016; Seth and Matzger 2017). 
MOF offers a variety of engineering features like high porosity, high surface area, synthesis in mild conditions, facile modification, predictable structures, and fine-tuning for the desired applications (Joseph et al. 2019; Chakraborty et al. 2021). Hence, the applications of MOF are seen in adsorption, catalysis, gas separation by capture, gas storage (hydrogen/ methane), drug delivery, biological imaging, and sensing ( $\mathrm{Li}$ et al. 2020). MOFs are increasingly being considered for the catalytic or adsorptive removal of inorganic metal cations, inorganic acids, oxyanions/ cations, nuclear wastes, inorganic anions and organic-pharmaceuticals and personal care products, artificial sweeteners and feed additives, agricultural products, organic dyes and industrial products. These are those contaminants that may commonly drain into the wastewater and water systems for consumption of human and animals (Mon et al. 2018). The ease of tuneability of MOF structures with varying metals and ligands for desired application has prompted researchers to explore the field of the multi-metallic and multiligand structures of MOFs. Bimetallic MOFs also have the ability to exploit the properties of both the metals bound into same structure by a common ligand or organic linker(Botas et al. 2010). Bimetallic MOFs have been found to be more efficient in adsorption, catalysis, semiconducting, gas separation, and storage than their precursor MOFs(Jiao et al. 2017). It has also been observed that many of such structures have good thermal and water stability, making them ideal for wastewater treatment (Li et al. 2019a; Masoomi et al. 2019). Another attractive property of bimetallic MOFs is their poor or low crystallinity. This provides site defects, locally distributed crystallinity, disorders in long-range in crystal structures imparting more sites for action ( $\mathrm{Li}$ et al. 2019b; Wu et al. 2021).

In this study, we have synthesized a bimetallic Iron-Aluminium-Benzene-1,4-dicarboxylic acid (Fe/Al (BDC)) (Chatterjee et al. 2021) MOF by a cost-effective hydrothermal synthesis method. The aim is to use the material to observe the adsorption behaviour of Rhodamine B dye in batch and effectively in the unique hybrid FeAl(BDC)-River sand fixed-bed column simulated filtration process. The adsorbent has also been tested on multiple dyes i.e. Malachite green (MG), Methylene blue (MB), Crystal violet (CV), and Methyl orange (MO) to asses its applicability and potential on other dyes. The adsorbent material FeAl(BDC) was used alongside river sand in the fixed-bed column study. This was carried out to improve the efficacy of the material and, most importantly, to replicate a simple water filtration unit's mechanism. The control studies have also been conducted to ensure the potential of $\mathrm{FeAl}(\mathrm{BDC})$ for various applications. 


\section{Experimental section}

\subsection{Chemicals}

Ferric Nitrate Nonahydrate $\left(\mathrm{Fe}\left(\mathrm{NO}_{3}\right)_{3} .9\left(\mathrm{H}_{2} \mathrm{O}\right)\right)$, Aluminum Nitrate Nonahydrate $\left.\left(\mathrm{Al}\left(\mathrm{NO}_{3}\right)_{3.9} . \mathrm{H}_{2} \mathrm{O}\right)\right)$, Terethalic acid (i.e. Benzene-1,4-dicarboxylic acid or BDC, $\left.\mathrm{C}_{6} \mathrm{H}_{4}\left(\mathrm{CO}_{2} \mathrm{H}\right)_{2}\right)$, Dimethylformamide (DMF), Nitric acid $\left(\mathrm{HNO}_{3}\right)$ were bought from Merck, India. Various dyes like Malachite green (MG), Methylene blue (MB), Crystal violet (CV), Rhodamine B (RhB) and Methyl orange (MO) were also obtained from Merck, India and used as supplied. Sand was obtained from Ganges river sediment deposits in upstream of Kanpur, India. Deionized (DI) water, conductivity $18 \mathrm{M} \Omega / \mathrm{cm}$ was used throughout in this study.

\subsection{Synthesis}

The bimetallic FeAl(BDC) MOF was synthesized by the solvothermal method. In detail, Ferric Nitrate Nonahydrate (0.001 moles), Aluminium Nitrate Nonahydrate (0.001 moles) and BDC (0.002 moles) were completely dissolved in $65 \mathrm{ml}$ of DMF. The obtained solution was placed in a $100 \mathrm{~mL}$ Teflon lined hydrothermal autoclave and was subjected to heating at $180{ }^{\circ} \mathrm{C}$ for 24 hours. The as obtained yellowish-white precipitate denoted as $\mathrm{FeAl}(\mathrm{BDC})$ was filtered and washed with Ethanol, followed by DI water to remove unreacted components. Finally, the product was dried in a vacuum oven overnight at $60{ }^{\circ} \mathrm{C}$ and stored in glass vial for further studies. The river sand was manually cleaned, washed with DI water for upto 5 times to remove any dirt or floating materials. It was then left in $10 \% \mathrm{HNO}_{3}$ solution for $48 \mathrm{~h}$, to remove any unwanted impurities in the sand. The sand was then again washed to obtain neutral $\mathrm{pH}$, dried and kept in closed container for further use.

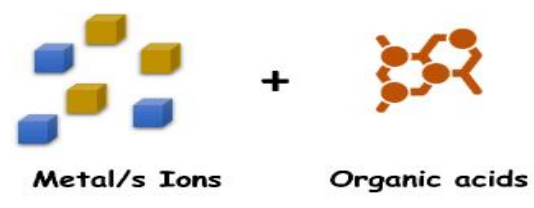

Organic acids

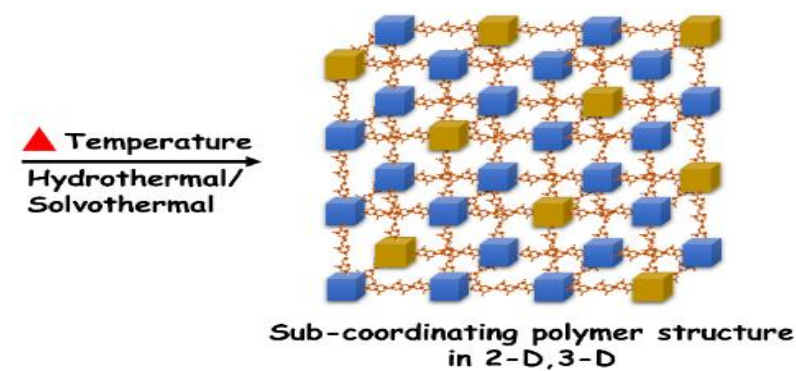

Fig 1. The basic concept of Metal-organic framework synthesis

\subsection{Characterization of $\mathrm{FeAl}(\mathrm{BDC}) \mathrm{MOF}$}

The X-Ray diffraction (XRD) patterns of the adsorbent were acquired using X'Pert Powder (PAN analytical instrument) within constraint $2 \theta$ between 5 to $80^{\circ}, \mathrm{Cu}-\mathrm{K} \alpha$ radiation $(\lambda=1.5405 \AA)$, and scan rate of $2^{\circ} \min ^{-1}$ at room temperature. Scanning Electron 
Microscope (SEM) from Carl-Zeiss MERLIN - GEMINI-2, was used to obtain micrograph of the powder adsorbent sample along with Energy Dispersive X-Ray Analysis (EDX). The FTIR spectra by Thermofisher (Nicolet 6700) analyzed thin pellets of the adsorbent material and exhausted adsorbent material mixed with $\mathrm{KBr}$ powder in the spectral range of 400 $4000 \mathrm{~cm}^{-1}$. Thermogravimetric analyzer (TGA) (NETZSCH technology, USA) was used to analyze thermal stability of the adsorbent material, placed in a platinum crucible, heated from 30 to $900{ }^{\circ} \mathrm{C}$ at $10{ }^{\circ} \mathrm{C} / \mathrm{min}$ rate in continuous nitrogen flow $(100 \mathrm{~mL} / \mathrm{min})$. The UVvis spectrophotometer of Shimadzu (Model UV-1900) was used for the spectroscopic study of dye. Adsorbent characteristics at different $\mathrm{pH}$ were examined in Zeta potential analyzer (Malvern zeta-sizer nano ZS90) at room temperature.

\subsection{Batch adsorption studies}

To understand the behaviour of the adsorbent-adsorbate, and the adsorption mechanism, as suggested in various literature, $\mathrm{pH}$, amount of dose, stirring speed, and different concentrations were studied. These studies include optimizing single parameters followed by kinetic, particle diffusion, isotherm, and thermodynamics studies for batch experiments. Plastic P.P. (polypropylene) bottles of $100 \mathrm{~mL}$ were used for batch adsorption. Initially, 25 ppm RhB solution was stirred with $1 \mathrm{~g} / \mathrm{L}$ of dose in multiple sets. At fixed time intervals, the bottles were collected and analyzed for RhB concentration via UV spectrophotometer. It was observed that equilibrium time was around 90 minutes, with more than $50 \%$ reduction within 10 minutes. The $\mathrm{pH}$ was investigated in the 3-8 range. The stirring speed effect was studied in the range of 200 to 800 rotations per minute (RPM). Dose study was carried out in the range of $0.2 \mathrm{~g} / \mathrm{L}-2.5 \mathrm{~g} / \mathrm{L}$ with constant RPM and fixed concentration of $25 \mathrm{mg} / \mathrm{L}$. Dose kinetics was also studied for $0.8,1$, and $1.2 \mathrm{~g} / \mathrm{L}$ doses. Concentration studies were carried out on 10, 25 and $50 \mathrm{mg} / \mathrm{L}$ of $\mathrm{RhB}$ and temperature studies for isotherm was carried out at 30,40 and $50{ }^{\circ} \mathrm{C}$ after optimization of all single parameters. Adsorption percentage or percentage removal was calculated by $\mathrm{Eq}(1)$. Similarly, adsorption capacities at any time and at equilibrium was calculated from $\mathrm{Eq}$ (2) and $\mathrm{Eq}$ (3). The post experiment calculation was obtained by equations below:

$$
\begin{aligned}
\% \mathrm{R} & =\frac{\mathrm{Co}-\mathrm{Ce}}{\mathrm{Co}} \times 100 \\
\mathrm{q}_{\mathrm{e}} & =\frac{\mathrm{Co}-\mathrm{Ce}}{\mathrm{W}} \times \mathrm{V} \\
\mathrm{q}_{\mathrm{t}} & =\frac{\mathrm{Co}-\mathrm{Ct}}{\mathrm{W}} \times \mathrm{V}
\end{aligned}
$$


Adsorption capacity and \% removal or efficiency were calculated by above formula. ' $R$ ' is the $\%$ removal, ' $\mathrm{C}_{\mathrm{e}}$ ' and ' $\mathrm{C}_{\mathrm{o}}$ ' are final and initial concentrations, respectively. Adsorption capacities are denoted by ' $\mathrm{q}_{\mathrm{e}}(\mathrm{mg} / \mathrm{g})$ ' at equilibrium and $\mathrm{q}_{\mathrm{t}}(\mathrm{mg} / \mathrm{g})$ at any given time ' $\mathrm{t}$ '. ' $\mathrm{V}$ ' and ' $\mathrm{m}$ ' are volume in litres and mass of adsorbate in gram, respectively.

\subsection{Column Adsorption studies}

Fixed-bed column studies were conducted in an upward flow mechanism with the help of a peristaltic pump (Miclins, Model no. pp-302CEX) in order to replicate constant flow. Flow rate $(2,5$ and $8 \mathrm{~mL} / \mathrm{min})$, Bed height $(5,9$ and $13 \mathrm{~cm})$ and concentration $(10,20$ and 40 $\mathrm{mg} / \mathrm{L}$ ) studies were conducted along with regeneration of the material in the column. Although experiments were conducted at room temperature, and $\mathrm{RhB}$ dye $\mathrm{pH}$ (5.38) was not changed, as mentioned earlier. The column used was fabricated from a borosilicate glass column of $1.5 \mathrm{~cm}$ in diameter and $20 \mathrm{~cm}$ in height.

FeAl(BDC) MOF was packed into column with proportion of sand in ratio 1:9 respectively. Sand and FeAl(BDC) MOF were mixed uniformly and no chemical interaction or bonding was intentionally obtained (Table1). This was executed in order to attain good hydraulic conductivity and limit blockage throughout the packed column bed, to lent maximum retention time for the liquid to pass through the material so that, adsorbent is used to its peak potential. Hence, for reference, $1 \mathrm{~g}$ of material and $9 \mathrm{~g}$ of sand mixed together, occupied a depth of $13 \mathrm{~cm}$ in the above-mentioned column. Glass wool $(4 \mathrm{~cm}$ at bottom as support and 3 $\mathrm{cm}$ on top as plug) was used to pack the material and restrict any movement inside the bed. This modification gave EBCT i.e. empty bed contact time of 7.855, 3.142 and 1.96375 min for flow rate of 2, 5 and $8 \mathrm{~mL} / \mathrm{min}$ respectively. The ratio of $\mathrm{FeAl}(\mathrm{BDC})$ : Sand is reported in Table 1.

Table 1. FeAl(BDC) MOF and Sand ratio in bed depths

\begin{tabular}{llll}
\hline Bed Depth Study & $5 \mathrm{~cm}$ & $9 \mathrm{~cm}$ & $13 \mathrm{~cm}$ \\
\hline Sand & $3.46 \mathrm{~g}$ & $6.23 \mathrm{~g}$ & $9 \mathrm{~g}$ \\
FeAl(BDC) & $0.38 \mathrm{~g}$ & $0.69 \mathrm{~g}$ & $1 \mathrm{~g}$ \\
Total adsorbent used & $3.84 \mathrm{~g}$ & $6.92 \mathrm{~g}$ & $10 \mathrm{~g}$ \\
\hline
\end{tabular}

215 Total volume passing through the column over time ' $t$ ' was calculated by Eq (4). Similarly, 216 total mass ( $\left.\mathrm{m}_{\text {total }}\right)$ was calculated using Eq (5). The adsorption capacity ( $\mathrm{q}_{\text {total }}$ and $\mathrm{q}_{\mathrm{eq}}$ ) were 217 calculated using Eq. (6) and (7). The contact time between adsorbate and adsorbent (EBCT), $\%$ Removal and Mass transfer zone (MTZ)was calculated using Eq. (8) (9) and (10) respectively (Cruz-Olivares et al. 2013). 


$$
\mathrm{m}_{\text {total }}=\left(\mathrm{C}_{0} * \mathrm{Q} * \mathrm{t}_{\text {total }}\right) /(1000)
$$

$\mathrm{q}_{\text {total }}=\frac{\mathrm{Q}}{1000 \mathrm{~W}} \int_{0}^{\mathrm{t}_{\text {total }}}\left(\mathrm{C}_{0}-\mathrm{C}_{\mathrm{t}}\right) \mathrm{dt}$

$$
\mathrm{q}_{\mathrm{eq}}=\frac{\mathrm{q}_{\text {total }}}{\mathrm{W}}
$$

$$
\mathrm{EBCT}=\frac{\mathrm{Z} * \mathrm{~S}}{\mathrm{Q}}
$$

$\% \mathrm{R}=\left(\frac{\mathrm{q}_{\text {total }}}{\mathrm{m}_{\text {total }}}\right) * 100$

$\mathrm{MTZ}=\mathrm{Z}\left(1-\frac{\mathrm{t}_{\mathrm{b}}}{\mathrm{t}_{\mathrm{sat}}}\right)$

Where, $C_{o}$ and $C_{t}(\mathrm{mg} / \mathrm{L})$ are the concentration at inlet and outlet respectively. $\mathrm{Q}(\mathrm{mL} / \mathrm{min})$ is flow rate. $\mathrm{Z}(\mathrm{cm})$ is height and is the cross-sectional area for the fixed-bed column. W $(\mathrm{g})$ represents weight of the adsorbent i.e. $\mathrm{FeAl}(\mathrm{BDC}) \mathrm{MOF}$ and ' $\mathrm{t}_{\mathrm{total}}$ ' ( $\mathrm{min}$ ) is overall flow time.

\section{Results and discussion}

\subsection{Characterization of $\mathrm{FeAl}(\mathrm{BDC}) \mathrm{MOF}$}

\subsubsection{Scanning electron microscopy}

The morphology of the FeAl(BDC) was observed (Fig 2), and EDS was obtain for elemental mapping of the sample. Images at high magnification (scale bar $200 \mathrm{~nm}$ ) clearly show the formation of two differentiable but inseparable rod /bar-like crystal structures. These crystals tend to aggregate and closely overlap each other, with one type of crystal clearly bigger than the other. EDS analysis shows the composition of MOF as $\mathrm{Al}, \mathrm{Fe}, \mathrm{C}, \mathrm{O}, \mathrm{N}$ in the sample. Moreover, the homogenous distribution of the elements mentioned above is confirmed in the elemental mapping of the FeAl(BDC) MOF. Both MIL53(Fe) and MIL53(Al) findings were correlated with synthesized adsorbent in the Paper (Du et al. 2011; Ai et al. 2014; Li et al. 2015; Pu et al. 2018; Amirilargani et al. 2019).

\subsubsection{Powder X-Ray diffraction (PXRD)} PXRD scan for FeAl(BDC) (Fig 3.a.) reveals major multiple sharp peaks conforming formation of MOF and similar to those of MIL-53(Fe) at 9.26, 9.87, 19.65, 20.88, 31.73, 32.55 and 9.07, 18.92, 23.60, 26.52, 33.55, 43.04 with MIL-53(Al). It is to be noted that the synthesized MOF has lower crystallinity than its precursors and the findings were similar in literature (Ai et al. 2014; Li et al. 2015; Pu et al. 2018; Amirilargani et al. 2019).

\subsubsection{FTIR-Fourier transform infrared spectroscopy}

The characteristic peaks obtained in FTIR spectra (Fig 3 b) for $\mathrm{FeAl}(\mathrm{BDC}$ ) have significant peaks at $577 \mathrm{~cm}^{-1}$ and $1014 \mathrm{~cm}^{-1}$, attributed to Fe-O and $\mathrm{Al}-\mathrm{O}$ bonds, respectively. The 
peaks for Carboxylate groups stretching can be observed in the spectra with signature peaks at 1577 (asymmetric) and 1405 (symmetric) $\mathrm{cm}^{-1}$, followed by $\mathrm{C}-\mathrm{H}$ bond vibration for benzene at $750 \mathrm{~cm}^{-1}$ coming from dicarboxylate in BDC. $\mathrm{C}=\mathrm{C}$ an aromatic bond vibration may depict the adsorbed $\mathrm{RhB}$ onto the adsorbent in range 1528 to $1542 \mathrm{~cm}^{-1}$, which only appears in spent FeAl(BDC) (Banerjee et al. 2012; Vu et al. 2015; Yan et al. 2015; Postai et al. 2016).

\subsubsection{TGA- Thermogravimetric analysis}

Zone I and Zone II (Fig. 3c) depict initial weight loss occurring below $200{ }^{\circ} \mathrm{C}$ with the removal of water from the sample's surface, possible decomposition of DMF from pores, and stranded organic linker molecule. However, in zone III (Fig. 3c), very steep weight loss ( 400- $550{ }^{\circ} \mathrm{C}$ ) is observed due to the rapid decomposition of the terephthalate linker leading to the breakdown of MOF structure. The stability of the sample is less as compared to, but can be attributed similar to, combined properties of MIL-53(Al, Fe). Zone IV (Fig. 3c) depicts the formation of amorphous products, and weight loss is almost stable (Qian et al. 2013; Mishra et al. 2014)

\subsubsection{Zeta Potential}

The Zeta potential and isoelectric point were obtained by adjusting the $\mathrm{pH}$ of DIW to 2, 4, 6, $7,8,10$, and 12 with sodium hydroxide and nitric acid. $10 \mathrm{mg}$ of sample was dispersed in 25 $\mathrm{ml}$ of the maintained $\mathrm{pH}$ solution. The final $\mathrm{pH}$ of the solution was measured after 2 and 12 hrs. $\Delta \mathrm{pH}$ was calculated by measuring the difference between initial and final $\mathrm{pH}$. The plot between Initial $\mathrm{pH}$ and $\Delta \mathrm{pH}$ (Fig. $3 \mathrm{~d}$ ) showed an isoelectric point around $5 \mathrm{pH}$. The adsorbent has a negative surface charge at acidic $\mathrm{pH}$, and the charge increases with an increase in $\mathrm{pH}$ to the basic range. Hence, $\mathrm{RhB}$ and $\mathrm{Fe} \mathrm{Al}(\mathrm{BDC})$ adsorption mechanisms may favor electrostatic interaction (Zarenezhad et al. 2021). 

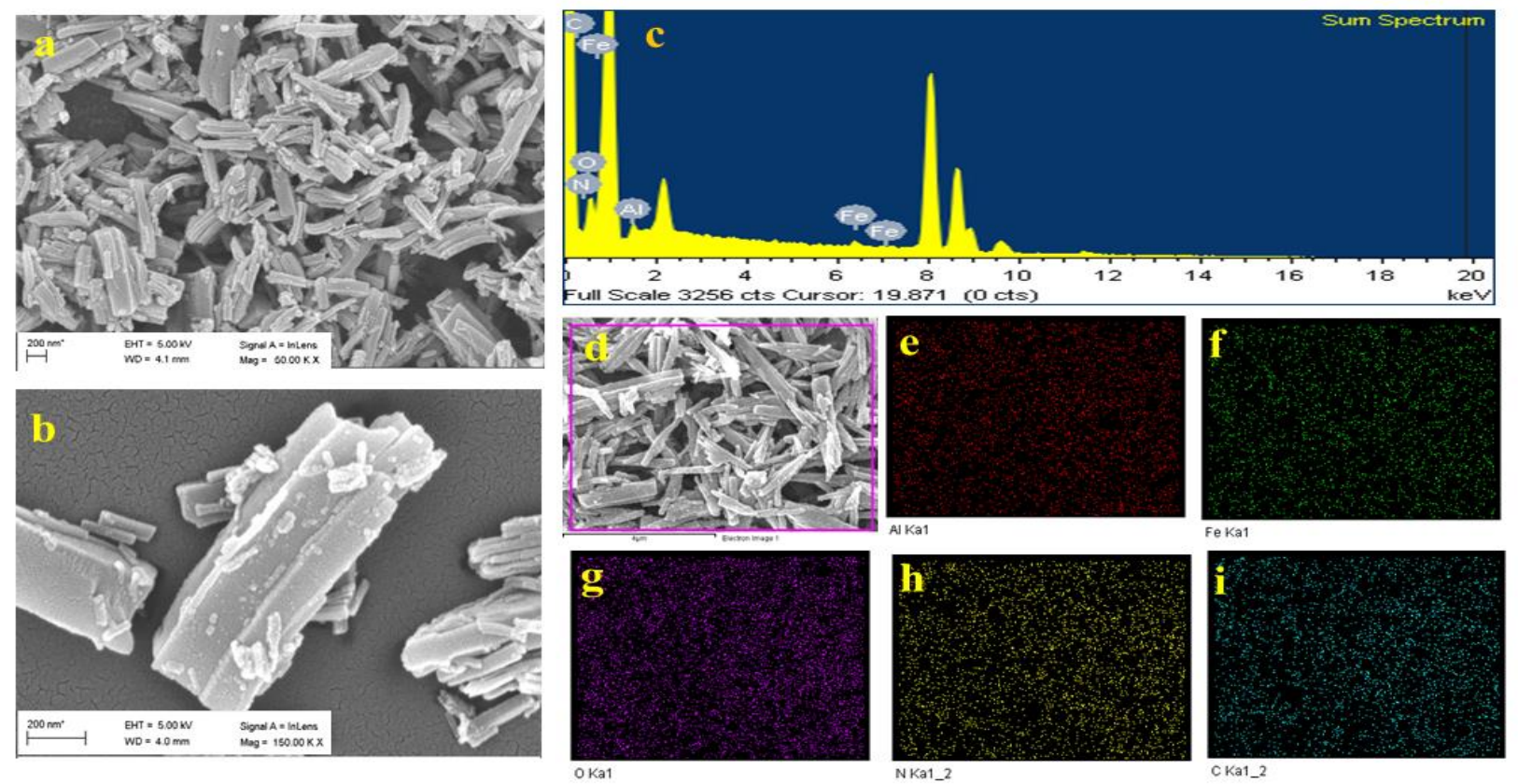

Fig 2. a and b are Micrograph of FeAl(BDC)MOF at $200 \mathrm{~nm}$ scale. c,d,e,f,g,h,i are

277 Elemental mapping of $\mathrm{FeAl}(\mathrm{BDC}) \mathrm{MOF}$ for elements and distribution of $\mathrm{Al}, \mathrm{Fe}, \mathrm{O}, \mathrm{N}, \mathrm{C}$ 278 respectively.
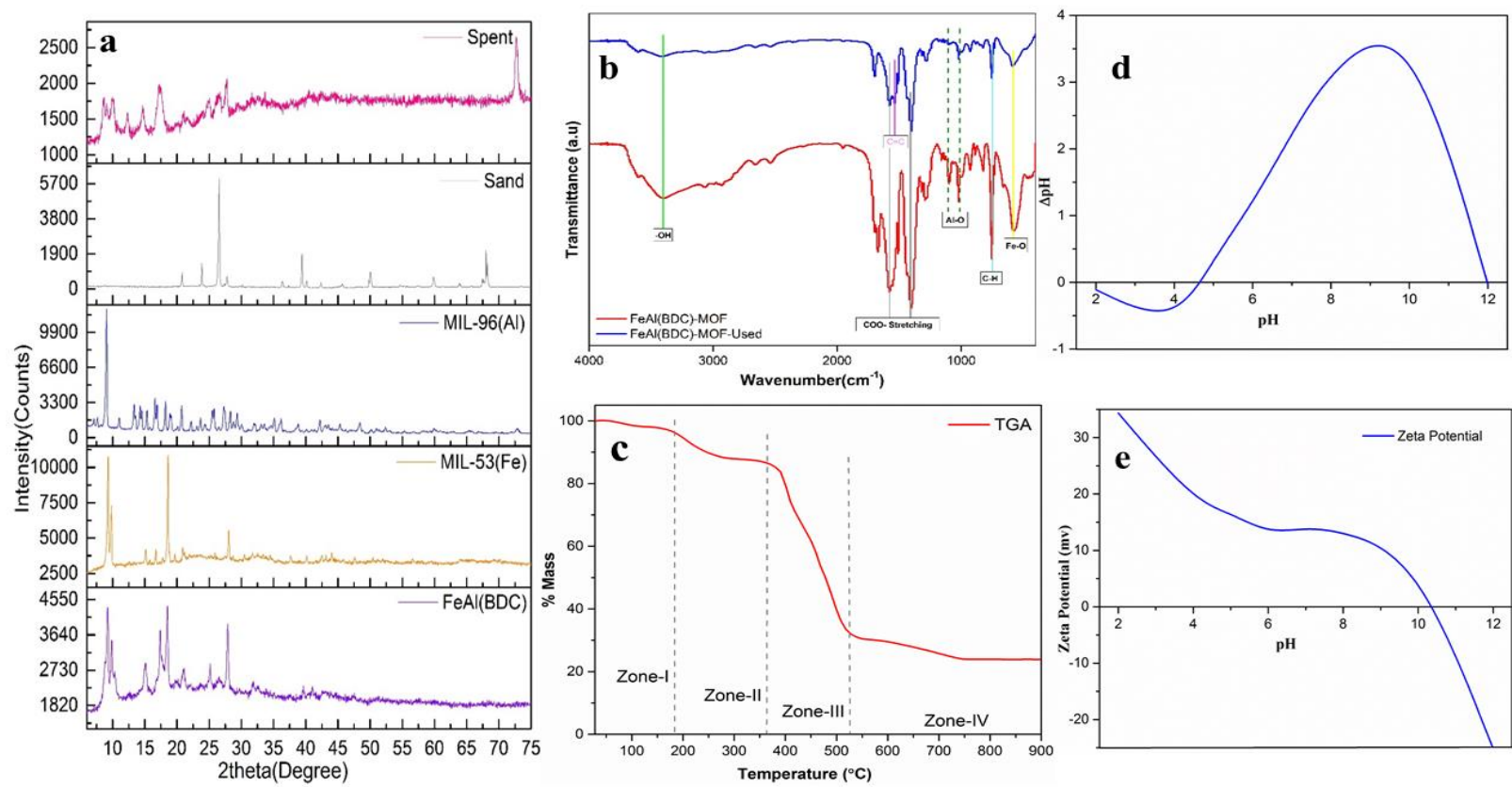

279 Fig 3. a. PXRD peak data for spent(after adsorption), Sand(Column), MIL-53(Al), MIL-

280 53(Fe), FeAl(BDC), b. FTIR spectra for adsorbent and spent FeAl(BDC), $\boldsymbol{c}$.

281 Thermogravimetric analysis(TGA), d. Isoelectric point measurement for FeAl(BDC), e. Zeta

Potential measurements 


\subsection{Batch Study}

\subsubsection{Optimization of factors affecting adsorption: $\mathrm{pH}, \mathrm{RPM} \&$ adsorbent dose}

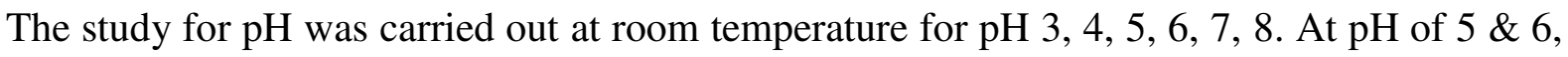
97-99\% removal of $\mathrm{RhB}$ was observed. It was observed that with the increase in $\mathrm{OH}^{-}$ions $\mathrm{RhB}$ adsorption decreased, which can be attributed to the change of surface charge on adsorbent material with increased $\mathrm{pH}$. It should be noted that RhB solution's $\mathrm{pH}$ stayed around 5.36 \pm 0.2 ; hence, no change to $\mathrm{pH}$ was carried out for further experiments (Fig 4a). A stirring speed study was optimized for a fixed dose of $1 \mathrm{~g} / \mathrm{L}$ and $25 \mathrm{mg} / \mathrm{L}$ of dye concentration for 90 minutes (Fig 4b). Dose study was carried out at an optimum concentration of $25 \mathrm{mg} / \mathrm{L}$ of $\mathrm{RhB}$ for 90 minutes with adsorbent dose variation of $0.5-2.5$ $\mathrm{mg} / \mathrm{L}$. It was observed that at doses of $0.9,1,1.50 \mathrm{~g} / \mathrm{L}$, the adsorbent attained more than $90 \%$ removal efficiency (Fig 4c). It was also observed that $70-75 \%$ of the removal was obtained in the first $5 \mathrm{~min}$ of the experiment and $85-90 \%$ within 20 minutes of contact. Adsorption gained 99\% efficiency within 90 minutes and reached saturation after that due to blockage or saturation of the adsorption sites. The experiment was extended to few more hours to observe desorption if any. The initial concentration of 10, 20, 30, 40, 50 and $60 \mathrm{mg} / \mathrm{L}$ and fixed adsorbent dose of $1 \mathrm{~g} / \mathrm{L}$ efficiency was investigated. The rate of removal increased upto 50 $\mathrm{mg} / \mathrm{L}$, but limited adsorbent dose saturated quickly with higher concentration. Hence, no significant removal was observed beyond $50 \mathrm{mg} / \mathrm{L}$. 

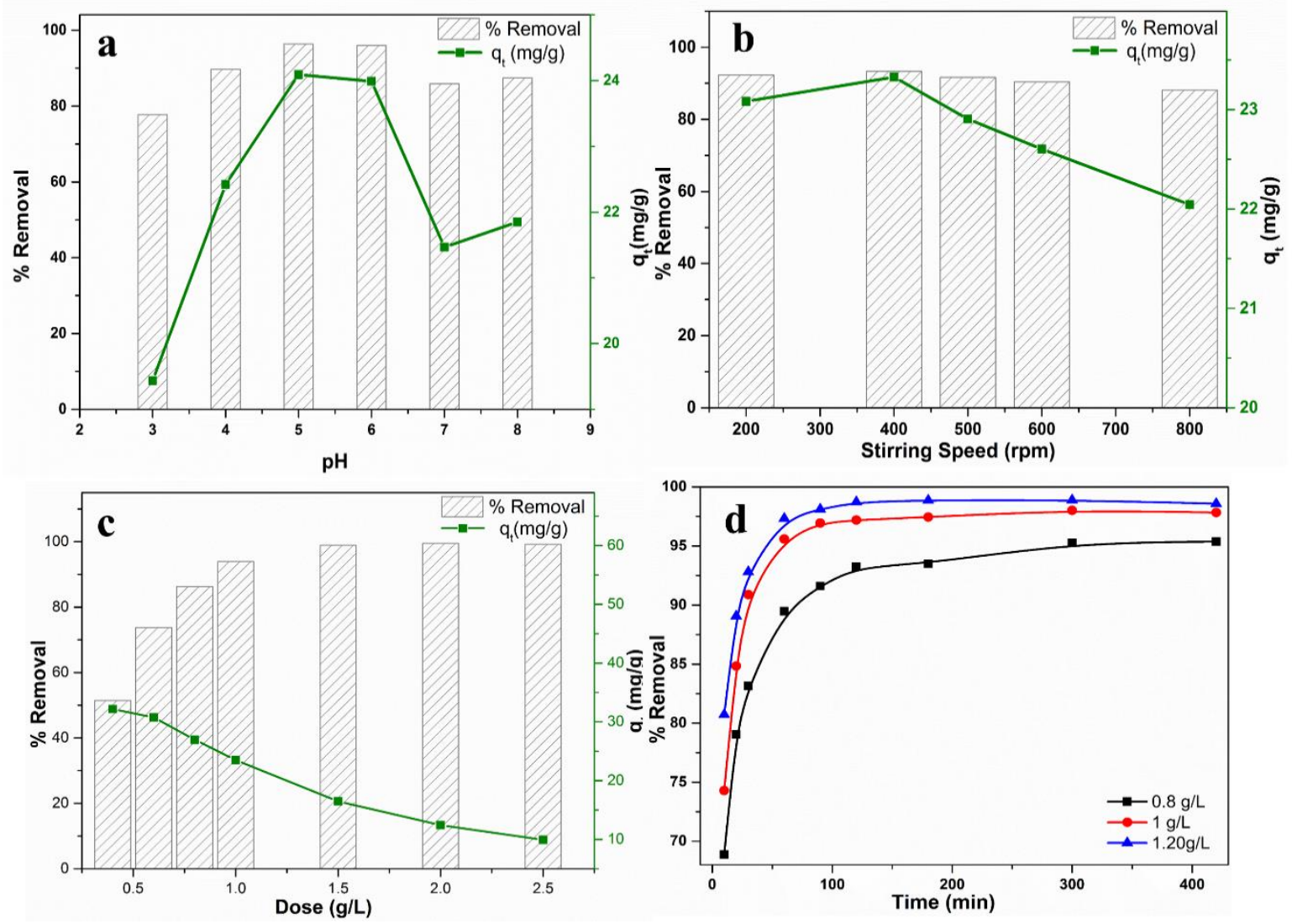

303

Fig 4. a. \%Removal $v / s p H, \boldsymbol{b}$. \%Removal $v / s$ RPM, c. \% Removal $v / s$ Dose, d. \% Removal $v / s$ dose, kinetics for 0.8, 1, $1.2 \mathrm{~g} / \mathrm{L}$., Conditions: $C_{o}=25 \mathrm{mg} / \mathrm{L}$, Time $=90$ minutes, $p H=3-8$, Dose $=0.4-2.5 \mathrm{~g} / \mathrm{L}$, and Temperature $=30^{\circ} \mathrm{C}$, Stirring speed $=200 \pm 20 \mathrm{rpm}$.

\subsubsection{Kinetics based on the concentration}

The kinetic study determines the adsorption rates and evaluates the different optimized conditions for further study (Fig 5). A kinetic study was conducted, with optimum dose and concentration for a maximum time of $420 \mathrm{~min}$. For a better understanding of the experiments, nonlinear equations are used. Kinetics at $\mathrm{RhB}$ concentration $(10,25$ and $50 \mathrm{mg} / \mathrm{L})$ was studied by Pseudo first order (Eq.10), Pseudo second-order (Eq.11), Elovich model (Eq.12) and Intraparticle diffusion model (Eq.13)(Wang and Guo 2020a).

$$
q_{t}=q_{e}\left(1-\exp \left(-\mathrm{k}_{1} \mathrm{t}\right)\right)
$$

$$
q_{t}=\left(k_{2}^{2} q_{e}^{2} \mathrm{t}\right) /\left(1+k_{2} q_{e} t\right) \& \mathrm{~h}=k_{2} q_{e}^{2}
$$


Where, ' $\mathrm{q}_{\mathrm{t}}$ ' and ' $\mathrm{q}_{\mathrm{e}}$ ' are the adsorption capacities at time ' $\mathrm{t}$ ' and at equilibrium with units $(\mathrm{mg} / \mathrm{g}) \cdot \mathrm{k}_{1}\left(\min ^{-1}\right), \mathrm{k}_{2}(\mathrm{~g} / \mathrm{mg} \min )$, are the pseudo first-order and the pseudo second-order rate constants. $\mathrm{h}(\mathrm{mg} / \mathrm{g} \mathrm{min}), \alpha(\mathrm{mg} / \mathrm{g} \min )$ are the initial adsorption rate, $\mathrm{t}$ is contact time in min, $\beta$ $(\mathrm{g} / \mathrm{mg})$ is adsorption constant, $\mathrm{k}_{\mathrm{id}}(\mathrm{mg} / \mathrm{g} \mathrm{min})$ intraparticle diffusion rate constant, $\mathrm{t}$ is contact time in $\min , \mathrm{c}(\mathrm{mg} / \mathrm{g})$ is constant of any experiment.
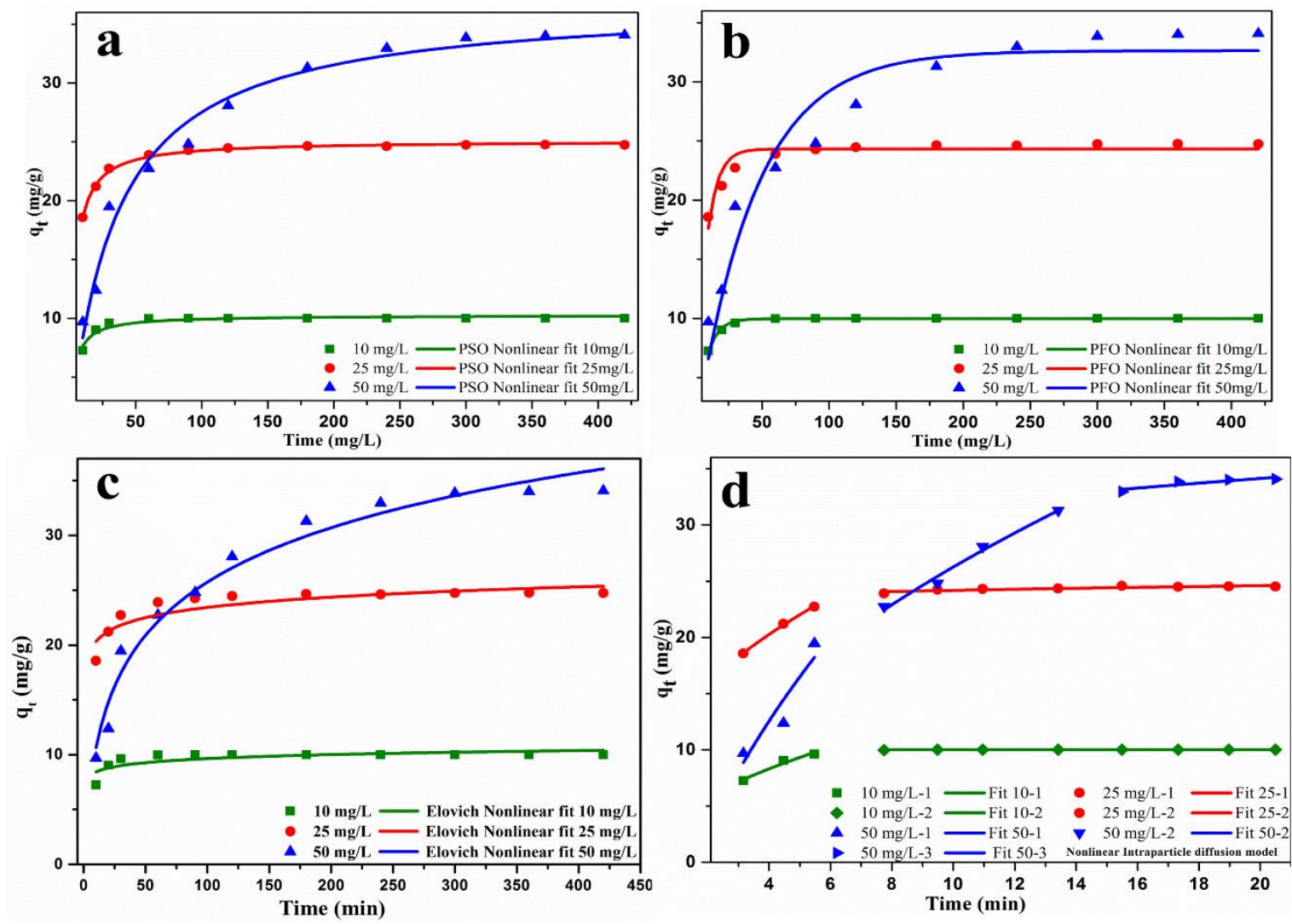

Fig 5. a. PSO nonlinear fit, b. PFO nonlinear fit, c. Elovich nonlinear fit, d. IPD model. Conditions: $C_{o}=10,25$, and $50 \mathrm{mg} / \mathrm{L}$, Time $=420$ minutes, $p H=5.36 \pm 0.2$, Dose $=1 \mathrm{~g} / \mathrm{L}$, Stirring speed $=200 \pm 20 \mathrm{rpm}$, and Temperature $=30^{\circ} \mathrm{C}$.

Table 2. Kinetic model parameters

\begin{tabular}{|c|c|c|c|c|c|c|c|c|c|c|}
\hline & & PFO & & & PSO & & & Elovi & model & \\
\hline $\begin{array}{l}\mathrm{C}_{\mathrm{o}} \\
(\mathrm{mg} / \mathrm{L} \\
)\end{array}$ & $\begin{array}{l}\mathrm{q}_{\mathrm{e}, \operatorname{Exp}} \\
(\mathrm{mg} / \\
\mathrm{g})\end{array}$ & $\begin{array}{l}\mathrm{k}_{1} \\
\left(\min ^{-1}\right)\end{array}$ & $\begin{array}{l}\mathrm{q}_{\mathrm{e}, \mathrm{Cal}} \\
(\mathrm{mg} / \\
\mathrm{g})\end{array}$ & $\mathrm{R}^{2}$ & $\begin{array}{l}\mathrm{k}_{2} \\
\left(\mathrm{~g} / \mathrm{mg}^{*}\right. \\
\mathrm{min})\end{array}$ & $\begin{array}{l}\text { qe, cal. } \\
(\mathrm{mg} / \\
\mathrm{g})\end{array}$ & $\mathrm{R}^{2}$ & $\begin{array}{l}\alpha \\
(\mathrm{g} / \mathrm{m} \\
\mathrm{g} * \mathrm{mi} \\
\mathrm{n})\end{array}$ & $\begin{array}{l}\mathrm{q}_{\mathrm{e}, \mathrm{cal} .} \\
(\mathrm{mg} / \mathrm{g}) \\
(1 / \beta)\end{array}$ & $\mathrm{R}^{2}$ \\
\hline 10 & 10 & 0.1259 & 9.97 & 0.99 & 0.0289 & 10.25 & 0.91 & $\begin{array}{l}4619 \\
5\end{array}$ & 0.52 & 0.57 \\
\hline 25 & 24.76 & 0.1289 & 24.32 & 0.86 & 0.0115 & 25.09 & 0.99 & $\begin{array}{l}4750 \\
18\end{array}$ & 1.34 & 0.76 \\
\hline 50 & 34.07 & 0.0225 & 32.62 & 0.93 & $7.88 \mathrm{E}-4$ & 36.95 & 0.97 & $\begin{array}{l}2.40 \\
2\end{array}$ & 7.30 & 0.97 \\
\hline
\end{tabular}


Table 3. Intraparticle diffusion model

\begin{tabular}{lllllllllll}
\hline $\begin{array}{l}\mathrm{C}_{\mathrm{o}} \\
(\mathrm{mg} /\end{array}$ & $\begin{array}{l}\mathrm{kip} 1 \\
\mathrm{~L})\end{array}$ & $\begin{array}{l}\mathrm{mg} / \mathrm{g} \times \mathrm{mi} 2 \\
\left.\mathrm{n}^{0.5}\right)\end{array}$ & $\begin{array}{l}\mathrm{kip} 2 \\
(\mathrm{mg} / \mathrm{g} \times \mathrm{mi} \\
\left.\mathrm{n}^{0.5}\right)\end{array}$ & $\begin{array}{l}\mathrm{kip3} \\
(\mathrm{mg} / \mathrm{g} \times \\
\left.\mathrm{min}^{0.5}\right)\end{array}$ & $\mathrm{C}_{\mathrm{i} 1}$ & $\mathrm{C}_{\mathrm{i} 2}$ & $\mathrm{C}_{\mathrm{i} 3}$ & $\mathrm{R}_{1}{ }^{2}$ & $\mathrm{R}_{2}{ }^{2}$ & $\mathrm{R}_{3}{ }^{2}$ \\
10 & 4.292 & 0.009 & & -0.28 & 9.96 & & 0.94 & 0.26 & \\
25 & 7.415 & 0.318 & & 5.42 & 23.17 & & 0.99 & 0.75 & \\
50 & 16.678 & 10.038 & 1.823 & -20.8 & -5.48 & 25.98 & 0.74 & 0.97 & 0.72 \\
\hline
\end{tabular}

329

330

331

332

333

334

335

336

337

338

339

340

341

342

343

344

345

346

347

348

349

350

351

352

353

354

355

The PSO model parameters fits better with experimental data and $\mathrm{R}^{2}$ ranges from $0.91,0.99$, and 0.97 for 10,25 , and $50 \mathrm{mg} / \mathrm{L}$ of $\mathrm{RhB}$ concentration, respectively as compared to the PFO model and Elovich model (Table 2). However, the value of 'qe ${ }_{c a l}$ ' is comparable with the 'qe Exp' values for PFO and PSO model but inconsistent with values from the Elovich model. Hence, it can be inferred that, adsorption process was dominated by pseudo second order kinetics and followed chemisorption mechanism. This also suggests that, adsorption is occurring at final stage and at multiple active sites on the adsorbent material FeAl(BDC) (Kadirvelu et al. 2005; Wang and Guo 2020a).

Experimental data were further analyzed for intraparticle diffusion (Fig 5e) to gather information on the adsorptive mechanism (Table 3 ). The plot between $\mathrm{qt} v / \mathrm{s} \mathrm{t}^{0.5}$ shows the concentration models, but none of the graphs passes through the origin. The graphs for 10 and $25 \mathrm{mg} / \mathrm{L}$ can be set into two stages and $50 \mathrm{mg} / \mathrm{L}$ into 3 stages. This suggests that intraparticle diffusion was not the rate-limiting step. The adsorption may also be occurring due to bulk diffusion of $\mathrm{RhB}$ into the adsorbent material and adsorption-desorption at equilibrium, determining mass transfer process (Gaaz et al. 2015; Rathour et al. 2020).

\subsubsection{Isotherm parameters study}

After optimizing various parameters, temperature study was conducted at three scales of 30 , $40,50{ }^{\circ} \mathrm{C}$ at concentration $(10,25,50,100,200 \mathrm{mg} / \mathrm{L})$, dose (1g/L) and $\mathrm{pH}(5.36 \pm 0.2)$.

Isotherm models have certain assumptions are to be considered. Langmuir model (Eq. 14) assumes the possibility of only monolayer adsorption with identical and finite adsorption sites. This considers homogenous adsorption with a molecule thickness on the adsorbent. The factor $\mathrm{R}_{\mathrm{L}}$, describes the attractive forces and distance relation in the adsorption process. It explains the possibility of adsorption as, irreversible below $\mathrm{R}_{\mathrm{L}}=0$, favourable between $0<$ $\mathrm{R}_{\mathrm{L}}<1$, linear at $\mathrm{R}_{\mathrm{L}}=1$, and unfavourable above $\mathrm{R}_{\mathrm{L}}>1$ (Weber and Chakravorti 1974). Freundlich model (Eq. 15), gains over Langmuir model, as it considers adsorption beyond 
monolayer and hence, can be applied to multi-layered and heterogeneous adsorption process(Zaheer et al. 2019; Wang and Guo 2020b). Dubinin-Radushkevich or D-R model (Eq. 16) was better understood on vapour adsorption on solids with an assumption that pore distribution on the adsorbent surface followed Gaussian energy distribution(Dąbrowski 2001; Wang and Guo 2020b). The Temkin model (Eq. 17), similar to the Freundlich model, applies to multilayer adsorption but ignores the extremely low and high concentration of adsorbate in the system (Abdi and Abedini 2020; Rathour et al. 2020; Wang and Guo 2020b).

$$
\text { Langmuir } q_{e}=\frac{q_{m} k_{l} C_{e}}{1+k_{l} C_{e}} \text { and } R_{L}=\frac{1}{1+k_{l} C_{0}}
$$

Freundlich $q_{e}=k_{f} C_{e}^{1 / n}$

Dubinin-Radushkevich (D-R) $q_{e}=q_{m} \exp \left(-\beta\left(R T \ln \left(1+\left(\frac{1}{C_{e}}\right)\right)\right)^{2}\right)$ and $E=\frac{1}{\sqrt{2 \beta}}(16)$

Temkin $q_{e}=B \ln \left(A_{t} C_{e}\right)$

Where $\mathrm{Ce}(\mathrm{mg} / \mathrm{L})$ is the outlet concentration of $\mathrm{RhB}$ in equilibrium time, $\mathrm{q}_{\mathrm{m}}(\mathrm{mg} / \mathrm{g})$ is the maximum adsorption capacity, and $\mathrm{qe}(\mathrm{mg} / \mathrm{g})$ is the amount of $\mathrm{RhB}$ adsorbed per unit weight of adsorbent. $\mathrm{k}_{\mathrm{L}}(\mathrm{L} / \mathrm{mg})$ is the energy of adsorption, $\mathrm{R}_{\mathrm{L}}$ is the separation factor, $\mathrm{k}_{\mathrm{f}}((\mathrm{mg} / \mathrm{g})$. $\left.(\mathrm{L} / \mathrm{mg})^{1 / n}\right)$ is the quantity of $\mathrm{RhB}$ adsorbed onto adsorbent for a given equilibrium concentration, $\mathrm{E}(\mathrm{K} . J . / \mathrm{mol})$ is the free energy in the adsorption process, $\beta \times 10^{-6}\left(\mathrm{~mol}^{2} / \mathrm{J}^{2}\right)$ is the constant related to the sorption energy, ' $\mathrm{A}_{\mathrm{t}}(\mathrm{L} / \mathrm{g})$ ' is the equilibrium binding constant corresponding to the maximum binding energy. ' $n$ ' is a measure of adsorption intensity, and $B$ is related to the heat of adsorption.
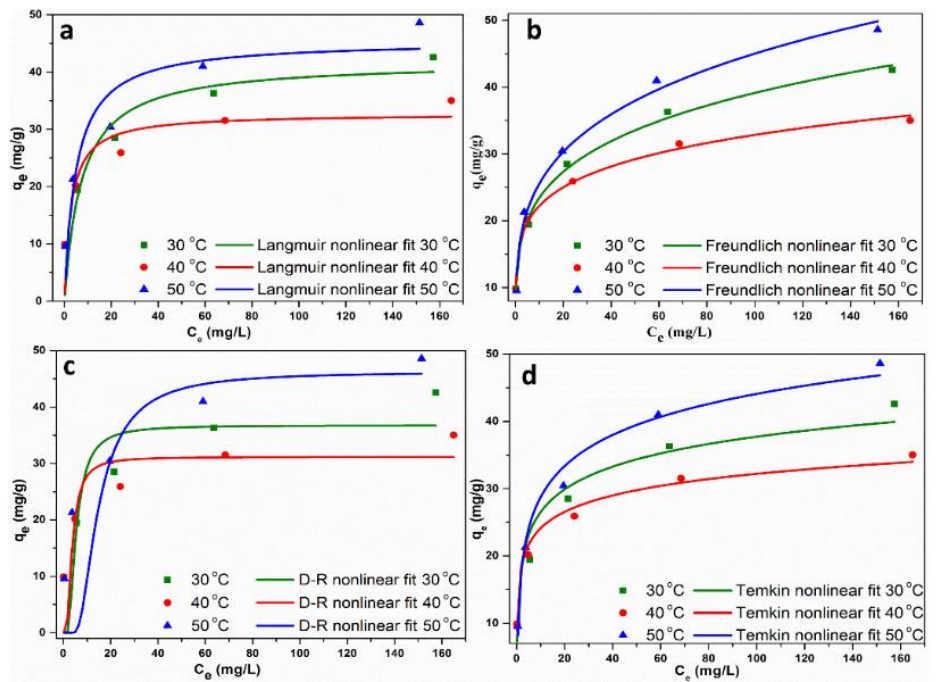

Fig 6. Nonliner fitting curve for Isotherm models a. Langmuir, b. Freundlich, c. DubininRadushkevich (D-R), and $\mathbf{d}$. Temkin model

Table 4. Isotherm models parameters 


\begin{tabular}{|c|c|c|c|c|c|c|c|c|c|}
\hline \multicolumn{6}{|c|}{ Langmuir } & \multicolumn{4}{|c|}{ Freundlich } \\
\hline $\begin{array}{l}\text { Temp. } \\
\left({ }^{\circ} \mathrm{C}\right)\end{array}$ & $\mathrm{q}_{\mathrm{m}}$, Exp. & $\mathrm{q}_{\mathrm{m}}$ cal. & $\mathrm{K}_{\mathrm{L}}$ & $\mathrm{R}_{\mathrm{L}}$ & $\mathrm{R}^{2}$ & $\mathrm{~K}_{\mathrm{F}}$ & & $1 / \mathrm{n}$ & $\mathrm{R}^{2}$ \\
\hline 30 & 42.59 & 41.86 & 0.14 & 0.035 & 0.98 & 14.04 & & .22 & 0.99 \\
\hline 40 & 35.03 & 32.73 & 0.35 & 0.014 & 0.98 & 15.06 & & .17 & 0.99 \\
\hline \multirow[t]{3}{*}{50} & 48.59 & 45.47 & 0.20 & 0.024 & 0.97 & 14.53 & & .24 & 0.98 \\
\hline & & \multicolumn{4}{|l|}{ Temkin } & \multicolumn{4}{|c|}{ Dubinin-Radushkevich (D-R) } \\
\hline & & $\mathrm{B}$ & $A$ & & $\mathrm{R}^{2}$ & $\mathrm{q}_{\mathrm{m}}$ cal. & $\beta$ & $\mathrm{E}$ & $\mathrm{R}^{2}$ \\
\hline 30 & 42.59 & 4.86 & & & 0.93 & 36.76 & $3.91 \mathrm{E}-6$ & $3.57 \mathrm{E}+02$ & 0.66 \\
\hline 40 & 35.03 & 3.51 & & & 0.97 & 31.17 & $1.85 \mathrm{E}-6$ & $5.19 \mathrm{E}+02$ & 0.55 \\
\hline 50 & 48.59 & 6.65 & & & 0.98 & 46.26 & $2.40 \mathrm{E}-5$ & $1.44 \mathrm{E}+02$ & 0.21 \\
\hline
\end{tabular}

A comparison of all four models is provided in Table 4, and nonlinear plots are given in Fig

6. The Langmuir, Freundlich and Temkin models have $\mathrm{R}^{2}$ values in the range of 0.97-0.98, 0.98-0.99, and 0.93-0.98, respectively, and have the closest fit to the experimental data over D-R model with $\mathrm{R}^{2}$ 0.21-0.66. The calculated adsorption capacity ( $\mathrm{q}_{\mathrm{m}}$ cal.) from the Langmuir model is comparable with the experimental adsorption capacity. The $\mathrm{R}_{\mathrm{L}}$ values for three temperatures are $0.349,0.0139$, and 0.0239 (all $0<\mathrm{R}_{\mathrm{L}}<1$ ) respectively which is favourable for adsorption. It should be noted that adsorption capacity as an overall increases with increase in temperature, with a significant drop at $40^{\circ} \mathrm{C}$ and then increased at $50^{\circ} \mathrm{C}$. However, the Freundlich model correlates better with the experimental data, followed by Langmuir and Temkin model. It also implies that multilayer, heterogeneous adsorption is dominant.

\subsubsection{Thermodynamic study model}

Thermodynamic studies on the adsorption process tend to explain the nature of the adsorption. Hence at three temperatures i.e., 30, 40, and $50{ }^{\circ} \mathrm{C}, \Delta \mathrm{G}^{0}$ (Gibbs free energy) was calculated using

Eq $(18,19,20)$ for adsorption of $\mathrm{RhB}$ on $\mathrm{FeAl}(\mathrm{BDC}) \mathrm{MOF}$.

395

$\ln \left(\mathrm{k}_{\mathrm{c}}\right)=\frac{\Delta \mathrm{S}^{0}}{\mathrm{R}}-\frac{\Delta \mathrm{H}^{0}}{\mathrm{R}}\left(\frac{1}{\mathrm{~T}}\right)$

$\Delta \mathrm{G}^{0}=-\mathrm{RT} \ln \left(\mathrm{k}_{\mathrm{c}}\right)$

397

$\mathrm{k}_{\mathrm{c}}=\mathrm{m} \frac{\mathrm{q}_{\mathrm{e}}}{\mathrm{C}_{\mathrm{e}}}$

398 Where, $\Delta \mathrm{H}^{\circ}(\mathrm{J} / \mathrm{mol})$ is the enthalpy change, $\Delta \mathrm{S}^{\circ}\left(\mathrm{J} / \mathrm{mol}\right.$. $\left.{ }^{\circ} \mathrm{K}\right)$ is the change in entropy, ' $\mathrm{k}_{\mathrm{c}}$ ' is 399 the distribution coefficient constant, $\mathrm{R}$ is the universal gas constant $(8.314 \mathrm{~J} / \mathrm{Kmol}), \mathrm{T}$ is the absolute temperature $\left({ }^{\circ} \mathrm{K}\right)$. ' $\mathrm{m}$ ' $(\mathrm{g} / \mathrm{L})$ is the amount of composite, 'qe' $(\mathrm{mg} / \mathrm{g})$ is $\mathrm{RhB}$ adsorbed at equilibrium and $\mathrm{Ce}(\mathrm{mg} / \mathrm{L})$ is the equilibrium concentration 
402

403

404

405

406

407

408

409

Table 6. Comparison of Batch adsorption capacities of FeAl(BDC) towards RhB with other adsorbents.

Table 5. Thermodynamic parameters

\begin{tabular}{lllll}
\hline \multirow{2}{*}{$\Delta \mathrm{H}^{\circ}(\mathrm{KJ} / \mathrm{mol})$} & $\Delta \mathrm{S}^{\circ}(\mathrm{J} / \mathrm{mol} \times \mathrm{K})$ & \multicolumn{4}{l}{$\Delta \mathrm{G}^{\circ}(\mathrm{KJ} / \mathrm{mol})$} & $30^{\circ}$ & $40^{\circ}$ & $50^{\circ}$ \\
20.186 & 76.85 & -3.10 & -3.86 & -4.63 \\
\hline
\end{tabular}

\begin{tabular}{|c|c|c|c|c|c|}
\hline Adsorbent & $\mathrm{pH}$ & $\begin{array}{l}\text { Eq. } \\
\text { time }\end{array}$ & $\begin{array}{l}\text { Initial conc } \\
\text { (mg/L) }\end{array}$ & qe $(\mathrm{mg} / \mathrm{g})$ & Reference \\
\hline Activated carbon & 5.7 & 150 & 20 & 16.12 & $\begin{array}{l}\text { (Kadirvelu et al. } \\
\text { 2005) }\end{array}$ \\
\hline $\begin{array}{l}\text { GO-PDA/PES-SPES } \\
\text { membrane }\end{array}$ & 4.0 & 180 & $2-70$ & 26.34 & (Wang et al. 2021) \\
\hline Fe@ZIF-67 (1\%) & 10 & 240 & 20 & 47.71 & (Nazir et al. 2021) \\
\hline $\begin{array}{l}\text { Beta zeolite with } \\
\mathrm{SiO}_{2} / \mathrm{Al}_{2} \mathrm{O}_{3}\end{array}$ & 3 & 60 & 5 & 27.97 & (Cheng et al. 2018) \\
\hline $\mathrm{MoS}_{2}$ & - & 120 & 40 & 26.18 & (Li et al. 2019c) \\
\hline $\mathrm{FeAl}(\mathrm{BDC})$ & 5.3 & 90 & 25 & 41.86 & PW \\
\hline
\end{tabular}

410

PW : Present Work

\subsubsection{Batch desorption, control and multiple dye adsorption study}

412 For the Desorption study(Fig 7a), two solutions of Acetone and Ethanol (5M) each were

413 used. The desorption efficiency was found to be $99 \%$ and $98 \%$, respectively, for $20 \mathrm{mg} / \mathrm{L}$ concentration of RhB dye in 30 minutes time. Pure Ethanol (98\%) was used for all desorption studies in batch and fixed-bed column. The adsorbent was removed by centrifugation and then desorbed in $50 \mathrm{ml}$ ethanol, followed by separation with centrifugation. Each time the process was followed in a similar manner of adsorption-desorption-DIW wash. The removal efficiency of the material decreased with each cycle and was observed to drop below $80 \%$ after $5^{\text {th }}$ cycle. Similarly, the adsorption capacity of the material decreased with each cycle. Overall, the adsorbent material holds good. The loss of various properties can be attributed to 
the loss of mass of the adsorbent in each cycle and the change in structural crystallinity (Fig 3a. Spent adsorbent XRD). The comparative study of $\mathrm{RhB}$ adsorption by sand and FeAl(BDC) showed negligible adsorption by sand $(<5 \%)$ in $90 \mathrm{~min}$. Hence, it can be deduced that $\mathrm{FeAl}(\mathrm{BDC}) \mathrm{MOF}$ obtains the overall adsorption in the system (Fig $7 \mathrm{~b}$ ). Furthermore, the adsorbent ability to remove multiple dyes, namely MG, MB, CV, and MO was evaluated. It was observed that the removal efficiency for all dyes were above $90 \%$, with the given dose of $1 \mathrm{~g} / \mathrm{L}$ and $20 \mathrm{mg} / \mathrm{L}$ of individual concentration (Fig $7 \mathrm{c}$ ).
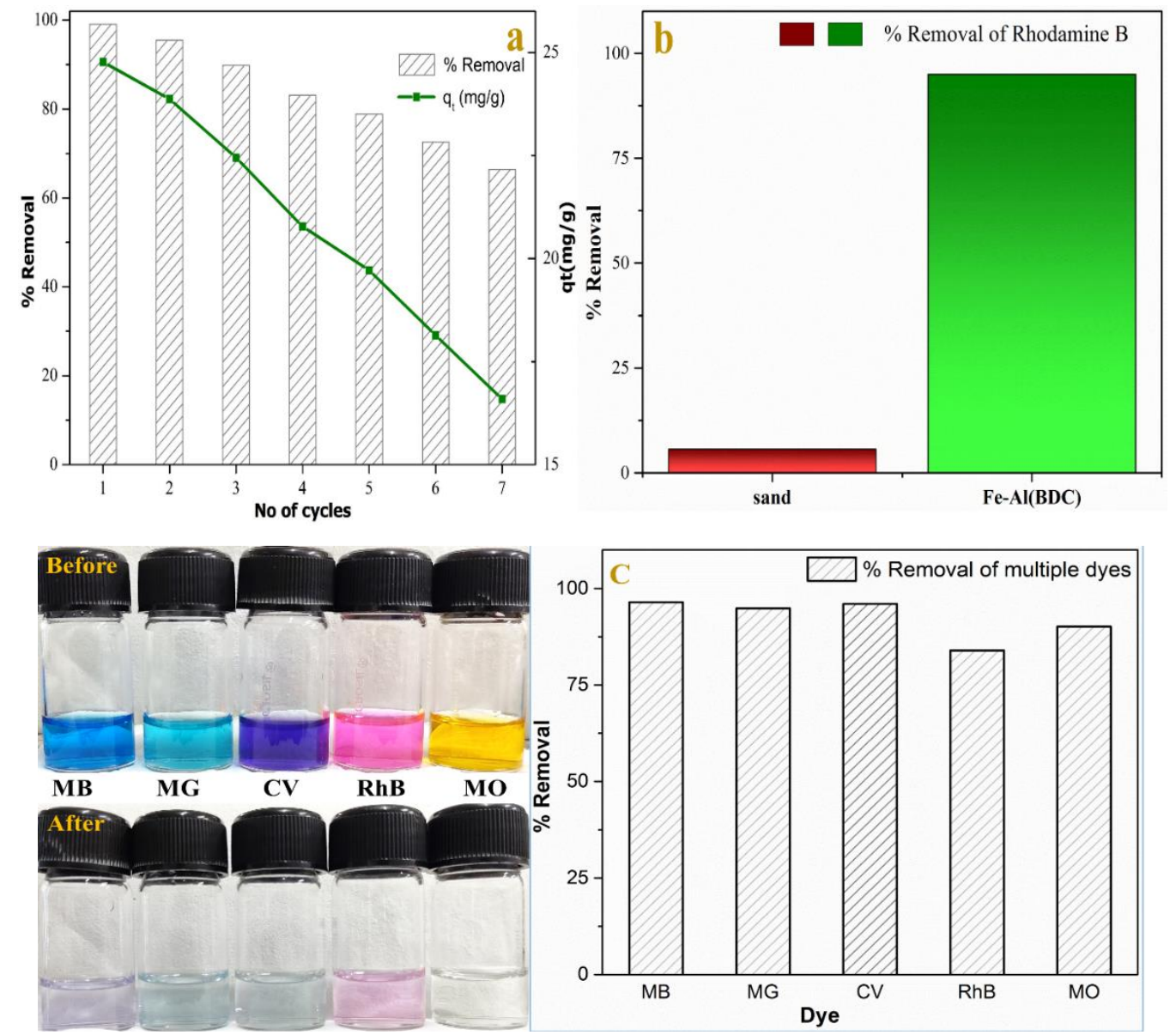

Fig 7. a. Desorption of RhodamineB from FeAl(BDC) and b. Comparative study on sand and $R h B, M O$.

\subsection{Column Study}

To understand the column adsorption mechanism, parameters affecting Rhodamine B adsorption on $\mathrm{FeAl}(\mathrm{BDC}) \mathrm{MOF}$ in continuous fixed-bed columns such as flow rate (Q), fixed-bed height (Z), and inlet concentration (Co) were studies in depth. To further understand the behaviour, experimental data were correlated and nonlinearly plotted with 

are given as follows(Han et al. 2008; Cruz-Olivares et al. 2013).

Thomas model

$\frac{\mathrm{C}_{\mathrm{t}}}{\mathrm{C}_{\mathrm{o}}}=\frac{1}{1+\exp \left(\left(\frac{\mathrm{k}_{\mathrm{TH}} * \mathrm{q}_{\mathrm{o}} * \mathrm{~W}}{\mathrm{Q}}\right)-\left(\mathrm{k}_{\mathrm{TH}} * \mathrm{C}_{\mathrm{o}} * \mathrm{t}\right)\right)}$

Yoon Nelson model

$\frac{\mathrm{C}_{\mathrm{t}}}{\mathrm{C}_{\mathrm{o}}}=\frac{1}{1+\exp \left(\mathrm{k}_{\mathrm{YN}} *(\tau-\mathrm{t})\right)}$

Bed depth-service time (BDST) model

$$
\frac{\mathrm{C}_{\mathrm{t}}}{\mathrm{C}_{\mathrm{o}}}=\frac{1}{1+\exp \left(\mathrm{k}_{\mathrm{BDST}} * \mathrm{C}_{\mathrm{o}}\left(\frac{\mathrm{N}_{\mathrm{o}}}{\mathrm{C}_{\mathrm{o}} * \mathrm{~V}} * \mathrm{~L}-\mathrm{t}\right)\right.}
$$

Dose-response (D-R) model

$$
\frac{\mathrm{C}_{\mathrm{t}}}{\mathrm{C}_{\mathrm{o}}}=1-\frac{1}{1+\left(\frac{\mathrm{C}_{\mathrm{o}} * \mathrm{Q} * \mathrm{t}}{\mathrm{q}_{\mathrm{o}} * \mathrm{X}}\right)^{\mathrm{a}}}
$$

440 Where $\mathrm{C}_{\mathrm{o}}(\mathrm{mg} / \mathrm{L})$ is the initial Concentration of $\mathrm{RhB}, \mathrm{C}_{\mathrm{t}}(\mathrm{mg} / \mathrm{L})$ is the Concentration of $\mathrm{RhB}$ 441 at any time ' $\mathrm{t}$ ', $\mathrm{q}_{\mathrm{o}}(\mathrm{mg} / \mathrm{g})$ is adsorption capacity, $\mathrm{t}(\mathrm{min})$ is adsorption time in $\mathrm{min}, \mathrm{W}(\mathrm{g})$ and $442 \mathrm{X}(\mathrm{g})$ are the weight of the total adsorbent. $\mathrm{Q}(\mathrm{mL} / \mathrm{min})$ and $\mathrm{v}(\mathrm{mL} / \mathrm{min})$ are the flow rates in 443 column, $\mathrm{k}_{\mathrm{TH}}(\mathrm{mL} / \mathrm{min} . \mathrm{mg})$ is the Thomas model rate constant, $\mathrm{k}_{\mathrm{YN}}\left(\mathrm{h}^{-1}\right)$ is the Yoon-Nelson rate constant, $\tau$ and $(\mathrm{h})$ is the required time for $50 \%$ adsorbate breakthrough. ${ }^{\prime} \mathrm{k}_{\mathrm{BDST}}$ (L/mg.min)' is rate of mass transfer from liquid to solid. $\mathrm{N}_{\mathrm{o}}(\mathrm{mg} / \mathrm{L})$ adsorption capacity of bed, L (cm) and Z (cm) are bed heights, 'a' is constant for Dose-response model.

\begin{tabular}{|c|c|c|c|c|c|c|c|c|c|c|c|}
\hline $\begin{array}{l}\mathrm{Q} \\
(\mathrm{mL} / \\
\mathrm{min})\end{array}$ & $\begin{array}{l}\mathrm{L} \text { or } \\
\mathrm{Z} \\
(\mathrm{cm})\end{array}$ & $\begin{array}{l}\text { Co } \\
\text { (mg/ } \\
\text { L) }\end{array}$ & $\begin{array}{l}\mathrm{t}_{\mathrm{B}} \\
(\min \\
)\end{array}$ & $\begin{array}{l}t_{E} \\
(\min \\
)\end{array}$ & $\begin{array}{l}\text { EBC } \\
T\end{array}$ & $\begin{array}{l}\text { MTZ } \\
(\mathrm{cm})\end{array}$ & $\begin{array}{l}\mathrm{m}_{\text {total }} \\
(\mathrm{g})\end{array}$ & $\begin{array}{l}V_{\text {eff }} \\
(\mathrm{mL})\end{array}$ & $\begin{array}{l}\mathrm{q}_{\text {total }} \\
(\mathrm{mg})\end{array}$ & $\begin{array}{l}\mathrm{q}_{\mathrm{eq}} \\
(\mathrm{mg} / \mathrm{g})\end{array}$ & $\% \mathrm{R}$ \\
\hline 2 & 13 & 20 & 840 & 1740 & 5.11 & 6.72 & 69.6 & 3480 & 44.03 & 44.03 & 63.26 \\
\hline 5 & 13 & 20 & 780 & 1740 & 2.05 & 7.17 & 176 & 8700 & 113.05 & 113.05 & 64.68 \\
\hline 8 & 13 & 20 & 240 & 750 & 1.28 & 8.84 & 120 & 6000 & 63.96 & 63.96 & 53.30 \\
\hline 5 & 5 & 20 & 270 & 840 & 0.79 & 3.69 & 84 & 4200 & 46.43 & 122.18 & 55.27 \\
\hline 5 & 9 & 20 & 570 & 1260 & 1.42 & 5.2 & 138 & 6750 & 84.35 & 120.67 & 61.12 \\
\hline 5 & 13 & 20 & 780 & 1740 & 2.05 & 7.17 & 176 & 8700 & 113.05 & 113.05 & 64.97 \\
\hline 5 & 13 & 10 & 1020 & 1990 & 2.05 & 6.33 & 99.5 & 9950 & 72.62 & 72.62 & 72.99 \\
\hline 5 & 13 & 20 & 780 & 1740 & 2.05 & 7.17 & 176 & 8700 & 113.05 & 113.05 & 64.97 \\
\hline 5 & 13 & 40 & 420 & 960 & 2.05 & 7.31 & 192 & 4800 & 109.42 & 109.42 & 56.99 \\
\hline
\end{tabular}

Table 7. Column parameters from design and experiments 


\subsubsection{Study with the varying flow rate}

450 The breakthrough curves (BTC) for feed flow rates at 2, 5, $8 \mathrm{~mL} / \mathrm{min}$ are shown in the graph,

451

452

453

454

455

456

457

458

459

460

461

462

463

464

465

466

467

468

469

470

471

472

473

474

475

476

477

478

479

480

481 along with various model fittings (Fig 8. a, b, c, and d). The bed height and Rhodamine B concentration were fixed at $13 \mathrm{~cm}$ and $20 \mathrm{mg} / \mathrm{L}$, respectively. It was observed that the flow rate had a significant effect on column performance and adsorbent efficiency. The maximum performance from experimental data of the column was obtained at the flow rates of 2, 5, 8 $\mathrm{mL} / \mathrm{min}$ was $63.26,64.68$, and 53.30\% removal efficiency with 44.03, 113.05, and 63.96 $\mathrm{mg} / \mathrm{g}$ uptake capacity, respectively (Table 6). There was a considerable decrease of \% removal and uptake capacity with increasing flow rate.

Further analyzing the graphs, it can be seen that at lower flow rates, the adsorbent material is able to capture dye molecules for a longer duration. When the availability of active sites reduces, the BTC sees a change in slope and reduced capacity. The feed rate provides enough residence time to attract dye molecules on the adsorbent and attain equilibrium. At a higher flow rate, the dye molecule gets very less contact time in the column, and adsorption equilibrium is not attained. This leads to a sudden and steeper rise in the BTC. The mass transfer zone (MTZ) increases at higher feed rates (Table 6). The mass transfer rate leads to faster saturation as the amount of dye molecule captured by unit bed depth increases with increasing flow rate (Saha et al. 2012; Afroze et al. 2016).

\subsubsection{Study with the varying bed height}

The breakthrough curves for column bed heights and fitted models at 5, 9, $13 \mathrm{~cm}$ are shown in the graph (Fig 8. e, f, g, and h). The flow rate and Rhodamine B concentration were fixed at $5 \mathrm{~mL} / \mathrm{min}$ and $20 \mathrm{mg} / \mathrm{L}$, respectively. The EBCT measured was $0.79,1.42$, and 2.05, respectively. It was observed that variation in bed height had a considerable effect on the removal efficiency of adsorbent. The maximum performance from experimental data of the column obtained at the bed heights of $5,9,13 \mathrm{~cm}$ was 55.27, 61.12, and $64.97 \%$ removal efficiency with $122.18,120.67$, and $113.05 \mathrm{mg} / \mathrm{g}$ uptake capacity, respectively. With the increase in bed height, the removal efficiency increased which is obviously due to the increased mass of adsorbent while the adsorption capacity decreased. The breakthrough time increased with an increase in bed height as 270, 570, and 780 minutes, respectively, which signifies that residence time increased, giving more interaction time between dye and adsorbent (Saha et al. 2012; Afroze et al. 2016). 


\subsubsection{Study with the varying concentration}

The breakthrough curves for Rhodamine B concentration at 10, 20, $40 \mathrm{mg} / \mathrm{L}$ and model fits are shown in the graph (Fig 8. i, j, k, and 1). The flow rate and bed height were constant at 5 $\mathrm{mL} / \mathrm{min}$ and $13 \mathrm{~cm}$, respectively. The maximum performance from experimental data of the column was obtained at the flow rates of $2,5,8 \mathrm{~mL} / \mathrm{min}$ was $72.99,64.97$, and $56.99 \%$ removal efficiency with $72.62,113.05$, and $109.42 \mathrm{mg} / \mathrm{g}$ uptake capacity, respectively. The breakthrough time decreased with increasing concentration, and at higher concentration a sharp rise, and at lower concentration a flattened rise in the BTC was observed. The saturation on active sites on the adsorbent saturated quickly at $40 \mathrm{mg} / \mathrm{L}$, thereby exhausting column earlier than other concentrations(Afroze et al. 2016; Karami et al. 2021).

\subsubsection{Model fitting for breakthrough curves}

Thomas model (Eq.21) (Table 7) shows a good uptake capacity at lower flow rates but abruptly drops at a higher flow rate. This sudden drop is observed across all the models and is consistent with the experimental data. It can be explained by residence time, which is not sufficient at a higher flow rate for adsorbate-adsorbent interaction. The $\mathrm{K}_{\mathrm{TH}}$ value of this model decreases with an increase in depth (i.e., increase in adsorption sites) of the fixed-bed, and hence a longer breakthrough time is observed. The Yoon-Nelson model (Eq.22) (Table 7) rate constant $\mathrm{K}_{\mathrm{YN}}$ also drops similar to $\mathrm{K}_{\mathrm{TH}}$ with an increase in bed height. The ' $\mathrm{t}_{\mathrm{b}}$ ' (Table 6) of experimental data was also comparable to $\tau$. The value of $\tau$ increases with the increase in bed depth (EBCT rises), and hence similar pattern is observed as the Thomas model. Bed depth-service time (BDST) model (Eq.23) (Table 8) fitting has better representation of parameters to support an upscale of the continuous fixed-bed column (Babazadeh et al. 2021). With the increase in bed height the 'K $\mathrm{BDST}_{\mathrm{BDT}}$ ' decreases while the value of ' $\mathrm{N}_{\mathrm{o}}$ ' has little variation. Dose Response (D-R) model (Eq.24) (Table 8) uptake capacity was similar to that of Thomas model in all the fixed-bed running conditions. All the above findings were similar in various literatures (Cruz-Olivares et al. 2013; Afroze et al. 2016; Podder and Majumder 2016; Karami et al. 2021). 

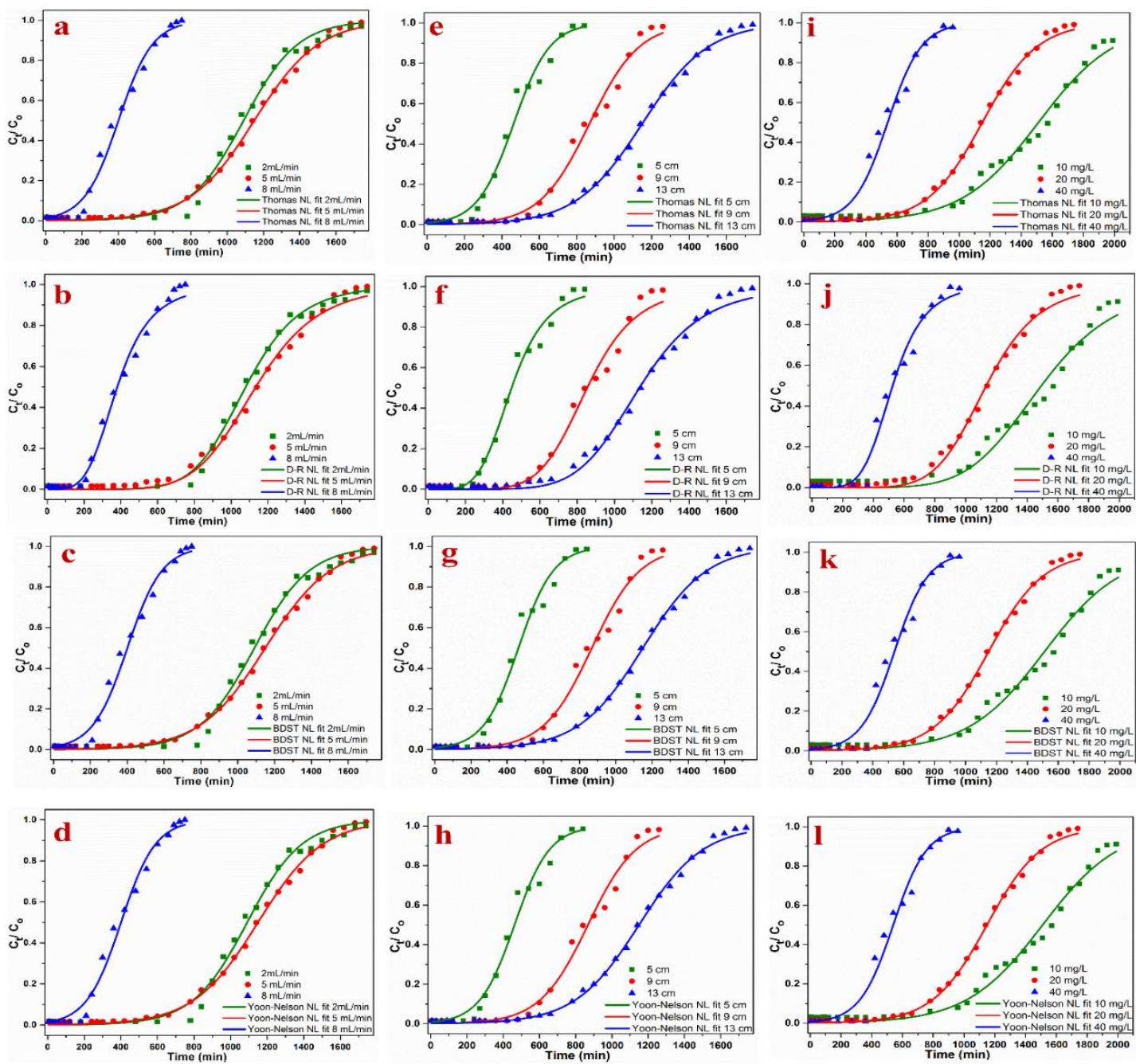

511 Fig 8. Flow rate (a to d), bed height (e to $\mathbf{h}$ ), and concentration (i to $\mathbf{l}$ ) variation modelled on

512 a, e, and i. Thomas model, b, f, and j. Dose-Response model, c, g and k. BDST model, d, h

513 and 1. Yoon-Nelson model respectively (Conditions : Flow rate: $Q=2,5,8 \mathrm{~mL} / \mathrm{min}$, Co=20

$514 \mathrm{mg} / \mathrm{L}, Z=13 \mathrm{~cm}, \mathrm{~m}=1 \mathrm{~g}$, Bed height: $Z=5,9,13 \mathrm{~cm}, \mathrm{~m}=0.38,0.69,1 \mathrm{~g}, Q=5 \mathrm{~mL} / \mathrm{min}, \mathrm{Co}=$

$51520 \mathrm{mg} / \mathrm{L}$, Rhodamine B concentration: $C o=10,20,40 \mathrm{mg} / \mathrm{L}, Z=13 \mathrm{~cm}, \mathrm{~m}=1 \mathrm{~g}, Q=5 \mathrm{~mL} / \mathrm{min}$ )

Table 8. Experimental data fitting on Thomas model and Yoon-nelson Model

\begin{tabular}{|c|c|c|c|c|c|c|c|c|}
\hline \multicolumn{4}{|c|}{ Column parameters } & \multicolumn{3}{|c|}{ Thomas model } & \multicolumn{2}{|c|}{ Yoon-nelson Model } \\
\hline $\begin{array}{l}\mathrm{Q} \\
(\mathrm{mL} / \mathrm{min} \\
)\end{array}$ & $\begin{array}{l}\mathrm{Z} \\
(\mathrm{cm})\end{array}$ & $\begin{array}{l}\text { Co } \\
(\mathrm{mg} / \mathrm{L})\end{array}$ & $\begin{array}{l}\text { W } \\
(\mathrm{g})\end{array}$ & $\begin{array}{l}\mathrm{K}_{\mathrm{TH}} \times 10^{-4} \\
(\mathrm{~mL} / \mathrm{mg} \times \mathrm{mi} \\
\mathrm{n})\end{array}$ & $\mathrm{q}_{\mathrm{o}}(\mathrm{mg} / \mathrm{g})$ & $\mathrm{R}^{2}$ & $\begin{array}{l}\mathrm{K}_{\mathrm{YN}} \\
(1 / \mathrm{min})\end{array}$ & $\boldsymbol{\tau}$ (min) \\
\hline 2 & 13 & 20 & 1 & 3.34 & 43.61 & 0.99 & 0.00669 & 1090 \\
\hline 5 & 13 & 20 & 1 & 2.82 & 114.94 & & 0.00565 & 1149 \\
\hline 8 & 13 & 20 & 1 & 5.31 & 64.13 & & 0.01062 & 401 \\
\hline 5 & 5 & 20 & 0.38 & 5.17 & 121.69 & 0.98 & 0.01035 & 462 \\
\hline 5 & 9 & 20 & 0.69 & 3.75 & 125.75 & & 0.00751 & 868 \\
\hline 5 & 13 & 20 & 1 & 2.82 & 114.94 & & 0.00565 & 1149 \\
\hline 5 & 13 & 10 & 1 & 4.04 & 75.568 & 0.98 & 0.00405 & 1511 \\
\hline
\end{tabular}




\begin{tabular}{llllllll}
5 & 13 & 20 & 1 & 2.82 & 114.94 & 0.00565 & 1149 \\
5 & 13 & 40 & 1 & 2.29 & 108.02 & 0.0092 & 540 \\
\hline
\end{tabular}

517 Data for BDST and Dose-Response is given below in table

Table 9. Experimental data fitting on Bed depth-service time (BDST) model and dose-response model

\begin{tabular}{|c|c|c|c|c|c|c|c|c|c|}
\hline \multicolumn{4}{|c|}{ Column parameters } & \multicolumn{3}{|c|}{$\begin{array}{l}\text { Bed depth-service time (BDST) } \\
\text { model }\end{array}$} & \multicolumn{3}{|c|}{$\begin{array}{l}\text { Dose-Response } \\
\text { model }\end{array}$} \\
\hline $\begin{array}{l}\mathrm{Q} \\
(\mathrm{mL} / \mathrm{min} \\
)\end{array}$ & $\begin{array}{l}\mathrm{Z} \\
(\mathrm{cm})\end{array}$ & $\begin{array}{l}\text { Co } \\
(\mathrm{mg} / \mathrm{L})\end{array}$ & $\begin{array}{l}\text { W } \\
(\mathrm{g})\end{array}$ & $\begin{array}{l}\text { KBDST } \times 10^{-4} \\
(\mathrm{~mL} / \mathrm{mg} \cdot \mathrm{min})\end{array}$ & $\begin{array}{l}\text { No } \\
(\mathrm{g} / \mathrm{L})\end{array}$ & $\mathrm{R}^{2}$ & $\begin{array}{l}\text { qo } \\
(\mathrm{g} / \mathrm{L})\end{array}$ & $\mathrm{a}$ & $\mathrm{R}^{2}$ \\
\hline 2 & 13 & 20 & 1 & 3.34 & 4247 & 0.99 & 43 & 7.35 & 0.99 \\
\hline 5 & 13 & 20 & 1 & 3.30 & 9555 & & 113 & 6.59 & \\
\hline 8 & 13 & 20 & 1 & 5.31 & 6245 & & 61 & 4.12 & \\
\hline 5 & 5 & 20 & 0.38 & 5.17 & 11708 & 0.98 & 118 & 4.68 & 0.98 \\
\hline 5 & 9 & 20 & 0.69 & 3.75 & 12204 & & 124 & 6.43 & \\
\hline 5 & 13 & 20 & 1 & 2.82 & 11192 & & 113 & 6.59 & \\
\hline 5 & 13 & 10 & 1 & 4.04 & 7358 & 0.97 & 75 & 5.98 & 0.97 \\
\hline 5 & 13 & 20 & 1 & 2.82 & 11192 & & 113 & 6.59 & \\
\hline 5 & 13 & 40 & 1 & 2.29 & 10518 & & 105 & 4.98 & \\
\hline
\end{tabular}

518

519

\subsubsection{Column regeneration study}

521 Column regeneration was performed for up to 3 runs, and conditions were followed similar to

522 batch study. The study was conducted at a fixed condition of $20 \mathrm{mg} / \mathrm{L}$ concentration of $\mathrm{RhB}$,

$5235 \mathrm{ml} / \mathrm{min}$ of flow rate, adsorbent dose of $0.38 \mathrm{~g}$, i.e. $4 \mathrm{~g}$ with sand and $5 \mathrm{~cm}$ of column height.

524 The column was run continuously for the study without breaking the cycle of adsorption-

525 desorption-DIW wash and without removing the adsorbent from the column. An average plot

526 is given in graph fig 9. It can be observed that rapid desorption occurs within 10 minutes of

527 the process. The desorption process starts attaining saturation after 40 minutes of continuous 528 run, and no considerable desorption occurs. 


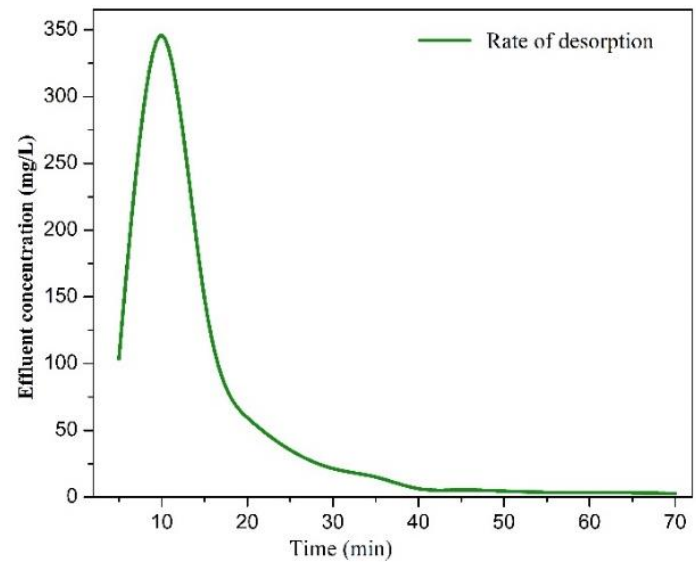

Fig 9. Rate of desorption of $\mathrm{FeAl}(B D C) \mathrm{MOF}$ in a column mode in regeneration study.

\section{Conclusion}

In the study reported, a bimetallic FeAl(BDC) MOF was synthesized and characterized. Its adsorption potential towards Rhodamine B dye was examined in the batch and unique hybrid adsorbent-sand column. Following are the significant outcomes of this study:

- The maximum uptake capacity of $\mathrm{FeAl}(\mathrm{BDC}) \mathrm{MOF}$ in optimized conditions for batch study $\left(\mathrm{pH}=5.36 \pm 0.2\right.$, stirring speed $=200 \pm 20$, temperature $=30^{\circ} \mathrm{C}$, adsorbent mass $=1.0 \mathrm{~g} / \mathrm{L}, \mathrm{RhB}$ concentration $=25 \mathrm{mg} / \mathrm{L}$ ) was $41.86 \mathrm{mg} / \mathrm{g}$.

- The adsorption of RhB dye was spontaneous and endothermic in nature, followed Pseudo second-order kinetics and Freundlich isotherm model.

- In the fixed-bed column study, the breakthrough was achieved in 13 hours with the effective treated volume of $8700 \mathrm{~mL}$ and MTZ of $2.05 \mathrm{~cm}$. In addition, \% removal of $\mathrm{RhB}$ dye in optimized conditions (flow rate $=5 \mathrm{~mL} / \mathrm{min}$, bed height $=13 \mathrm{~cm}$, adsorbent mass $=1 \mathrm{~g}, \mathrm{RhB}$ concentration $=20 \mathrm{mg} / \mathrm{L}$ ) was $64 \%$.

- The nonlinear kinetic models fitted with column study data depicted high correlation $\left(\mathrm{R}^{2}=0.975-0.998\right)$, and the experimental adsorption capacity ( $\left.\mathrm{q}_{\mathrm{exp}}\right)$ of $113.05 \mathrm{mg} / \mathrm{g}$, was found similar to calculated adsorption capacity ( $\left.\mathrm{q}_{\mathrm{cal}}\right)$ of Thomas and D-R's $114.94 \mathrm{mg} / \mathrm{g}$ and $113.41 \mathrm{mg} / \mathrm{g}$, respectively.

- The BDST model also shows a good fitting with the BTC, which is the suitable template to scale up the fixed-bed columns into possible filtration units.

Furthermore, the study also draws attention to the potential application of sand$\mathrm{FeAl}(\mathrm{BDC})$ based filters, etc., having various water treatment and filtration applications in various parts of the world, particularly having economically poor communities subjected to such pollutants. Hence, it is concluded that the as developed river sand$\mathrm{FeAl}(\mathrm{BDC})$ has the potential to treat multiple dyes (MB, MG, CV, RhB, MO) in 
continuous system and can also be utilized to treat polluted water with alike contaminations.

\section{Reference}

Abdi J, Abedini H (2020) MOF-based polymeric nanocomposite beads as an efficient adsorbent for wastewater treatment in batch and continuous systems: Modelling and experiment. Chem Eng J. doi: 10.1016/j.cej.2020.125862

Afroze S, Sen TK, Ang HM (2016) Adsorption performance of continuous fixed bed column for the removal of methylene blue (MB) dye using Eucalyptus sheathiana bark biomass. Res Chem Intermed. doi: 10.1007/s11164-015-2153-8

Ai L, Zhang C, Li L, Jiang J (2014) Iron terephthalate metal-organic framework: Revealing the effective activation of hydrogen peroxide for the degradation of organic dye under visible light irradiation. Appl Catal B Environ. doi: 10.1016/j.apcatb.2013.10.056

Aksu Z, Tezer S (2005) Biosorption of reactive dyes on the green alga Chlorella vulgaris. Process Biochem. doi: 10.1016/j.procbio.2004.06.007

Amini M, Arami M, Mahmoodi NM, Akbari A (2011) Dye removal from colored textile wastewater using acrylic grafted nanomembrane. Desalination. doi: 10.1016/j.desal.2010.09.014

Amirilargani M, Merlet RB, Hedayati P, et al (2019) MIL-53(Al) and NH2-MIL-53(Al) modified $\alpha$-alumina membranes for efficient adsorption of dyes from organic solvents. Chem Commun. doi: 10.1039/c9cc01624d

Babazadeh M, Abolghasemi H, Esmaeili M, et al (2021) Comprehensive batch and continuous methyl orange removal studies using surfactant modified chitosanclinoptilolite composite. Sep Purif Technol. doi: 10.1016/j.seppur.2021.118601

Banerjee A, Gokhale R, Bhatnagar S, et al (2012) MOF derived porous carbon-Fe $3 \mathrm{O} 4$ nanocomposite as a high performance, recyclable environmental superadsorbent. J Mater Chem 22:19694-19699. doi: 10.1039/c2jm33798c

Botas JA, Calleja G, Sánchez-Sánchez M, Orcajo MG (2010) Cobalt doping of the MOF-5 framework and its effect on gas-adsorption properties. Langmuir. doi: 10.1021/la100423a

Chakraborty G, Park IH, Medishetty R, Vittal JJ (2021) Two-Dimensional Metal-Organic Framework Materials: Synthesis, Structures, Properties and Applications. Chem. Rev. 
Charumathi D, Das N (2012) Packed bed column studies for the removal of synthetic dyes from textile wastewater using immobilised dead C. tropicalis. Desalination. doi: 10.1016/j.desal.2011.09.023

Chatterjee A, Jana AK, Basu JK (2021) Silica supported binary metal organic framework for removing organic dye involving combined effect of adsorption followed by photocatalytic degradation. Mater Res Bull. doi: 10.1016/j.materresbull.2021.111227

Chegeni M, Mehri M, Dehdashtian S (2021) Photocatalytic bauxite and red mud/graphitic carbon nitride composites for Rhodamine B removal. J Mol Struct. doi: 10.1016/j.molstruc.2021.130752

Chen AH, Chen SM (2009) Biosorption of azo dyes from aqueous solution by glutaraldehyde-crosslinked chitosans. J Hazard Mater. doi: 10.1016/j.jhazmat.2009.07.104

Cheng ZL, Li Y xiang, Liu Z (2018) Study on adsorption of rhodamine B onto Beta zeolites by tuning $\mathrm{SiO} 2 / \mathrm{A} 12 \mathrm{O} 3$ ratio. Ecotoxicol Environ Saf. doi: 10.1016/j.ecoenv.2017.11.005

Choudhary V, Patel M, Pittman CU, Mohan D (2020) Batch and Continuous Fixed-Bed Lead Removal Using Himalayan Pine Needle Biochar: Isotherm and Kinetic Studies. ACS Omega 5:16366-16378. doi: 10.1021/acsomega.0c00216

Cruz-Olivares J, Pérez-Alonso C, Barrera-Díaz C, et al (2013) Modeling of lead (II) biosorption by residue of allspice in a fixed-bed column. Chem Eng J. doi: 10.1016/j.cej.2013.04.101

Dạbrowski A (2001) Adsorption - From theory to practice. Adv. Colloid Interface Sci. 93:

Du JJ, Yuan YP, Sun JX, et al (2011) New photocatalysts based on MIL-53 metal-organic frameworks for the decolorization of methylene blue dye. J Hazard Mater. doi: 10.1016/j.jhazmat.2011.04.029

Gaaz TS, Sulong AB, Akhtar MN, et al (2015) Properties and applications of polyvinyl alcohol, halloysite nanotubes and their nanocomposites. Molecules 20:22833-22847. doi: 10.3390/molecules201219884

Gangu KK, Maddila S, Mukkamala SB, Jonnalagadda SB (2016) A review on contemporary Metal-Organic Framework materials. Inorganica Chim. Acta

Geetha Malini PS, Durgadevi P, Senthil Kumar N, Rani S (2020) Synthesis and characterisation of $\mathrm{CdO}$ nanoparticles: An efficient nanomaterial for the removal of Rhodamine B. Mater Today Proc. doi: 10.1016/j.matpr.2020.07.689

Gupta VK, Suhas (2009) Application of low-cost adsorbents for dye removal - A review. J. 
Environ. Manage. 90:

Han R, Ding D, Xu Y, et al (2008) Use of rice husk for the adsorption of congo red from aqueous solution in column mode. Bioresour Technol. doi: 10.1016/j.biortech.2007.06.027

Jiao Y, Pei J, Chen D, et al (2017) Mixed-metallic MOF based electrode materials for high performance hybrid supercapacitors. J Mater Chem A. doi: 10.1039/C6TA09805C

Joseph L, Jun BM, Jang M, et al (2019) Removal of contaminants of emerging concern by metal-organic framework nanoadsorbents: A review. Chem. Eng. J.

Kadirvelu K, Karthika C, Vennilamani N, Pattabhi S (2005) Activated carbon from industrial solid waste as an adsorbent for the removal of Rhodamine-B from aqueous solution: Kinetic and equilibrium studies. Chemosphere. doi: 10.1016/j.chemosphere.2005.01.047

Karami A, Sabouni R, Al-Sayah MH, Aidan A (2021) Adsorption potentials of iron-based metal-organic framework for methyl orange removal: batch and fixed-bed column studies. Int J Environ Sci Technol. doi: 10.1007/s13762-020-03103-2

Kiran I, Akar T, Ozcan AS, et al (2006) Biosorption kinetics and isotherm studies of Acid Red 57 by dried Cephalosporium aphidicola cells from aqueous solutions. Biochem Eng J. doi: 10.1016/j.bej.2006.07.008

Lellis B, Fávaro-Polonio CZ, Pamphile JA, Polonio JC (2019) Effects of textile dyes on health and the environment and bioremediation potential of living organisms. Biotechnol Res Innov. doi: 10.1016/j.biori.2019.09.001

Li C, Xiong Z, Zhang J, Wu C (2015) The Strengthening Role of the Amino Group in MetalOrganic Framework MIL-53 (Al) for Methylene Blue and Malachite Green Dye Adsorption. J Chem Eng Data. doi: 10.1021/acs.jced.5b00692

Li FL, Wang P, Huang X, et al (2019a) Large-Scale, Bottom-Up Synthesis of Binary MetalOrganic Framework Nanosheets for Efficient Water Oxidation. Angew Chemie - Int Ed. doi: 10.1002/anie.201902588

Li J, Bhatt PM, Li J, et al (2020) Recent Progress on Microfine Design of Metal-Organic Frameworks: Structure Regulation and Gas Sorption and Separation. Adv. Mater. 32:

Li J, Huang W, Wang M, et al (2019b) Low-Crystalline Bimetallic Metal-Organic Framework Electrocatalysts with Rich Active Sites for Oxygen Evolution. ACS Energy Lett. doi: 10.1021/acsenergylett.8b02345

Li Z, Meng X, Zhang Z (2019c) Equilibrium and kinetic modelling of adsorption of Rhodamine B on MoS2. Mater Res Bull. doi: 10.1016/j.materresbull.2018.11.012 Lu Q, Gao W, Du J, et al (2012) Discovery of environmental rhodamine B contamination in 

paprika during the vegetation process. J Agric Food Chem. doi: 10.1021/jf300067z

Masoomi MY, Morsali A, Dhakshinamoorthy A, Garcia H (2019) Mixed-Metal MOFs: Unique Opportunities in Metal-Organic Framework (MOF) Functionality and Design. Angew. Chemie - Int. Ed. 58:

660

661

662

663

664

665

666

667

668

669

670

671

672

673

674

675

676

677

678

679

680

681

682

683

684

685

686

687

688

689

Mishra P, Uppara HP, Mandal B, Gumma S (2014) Adsorption and separation of carbon dioxide using MIL-53(Al) metal-organic framework. In: Industrial and Engineering Chemistry Research.

Mon M, Bruno R, Ferrando-Soria J, et al (2018) Metal-organic framework technologies for water remediation: Towards a sustainable ecosystem. J. Mater. Chem. A

Nagaraja R, Kottam N, Girija CR, Nagabhushana BM (2012) Photocatalytic degradation of Rhodamine $\mathrm{B}$ dye under UV/solar light using $\mathrm{ZnO}$ nanopowder synthesized by solution combustion route. Powder Technol. doi: 10.1016/j.powtec.2011.09.014

Nazir MA, Bashir MS, Jamshaid M, et al (2021) Synthesis of porous secondary metal-doped MOFs for removal of Rhodamine B from water: Role of secondary metal on efficiency and kinetics. Surfaces and Interfaces. doi: 10.1016/j.surfin.2021.101261

Podder MS, Majumder CB (2016) Fixed-bed column study for As(III) and As(V) removal and recovery by bacterial cells immobilized on Sawdust/MnFe2O4 composite. Biochem Eng J. doi: 10.1016/j.bej.2015.09.008

Postai DL, Demarchi CA, Zanatta F, et al (2016) Adsorption of rhodamine B and methylene blue dyes using waste of seeds of Aleurites Moluccana, a low cost adsorbent. Alexandria Eng J. doi: 10.1016/j.aej.2016.03.017

Pu M, Guan Z, Ma Y, et al (2018) Synthesis of iron-based metal-organic framework MIL-53 as an efficient catalyst to activate persulfate for the degradation of Orange $G$ in aqueous solution. Appl Catal A Gen. doi: 10.1016/j.apcata.2017.09.021

Qian X, Yadian B, Wu R, et al (2013) Structure stability of metal-organic framework MIL-53 (Al) in aqueous solutions. Int J Hydrogen Energy 38:16710-16715. doi: 10.1016/J.IJHYDENE.2013.07.054

Rathour RKS, Bhattacharya J, Mukherjee A (2020) Selective and multicycle removal of $\mathrm{Cr}(\mathrm{VI})$ by graphene oxide-EDTA composite: Insight into the removal mechanism and ionic interference in binary and ternary associations. Environ Technol Innov. doi: 10.1016/j.eti.2020.100851

Richardson SD, Willson CS, Rusch KA (2004) Use of rhodamine water tracer in the marshland upwelling system. Ground Water. doi: 10.1111/j.1745-6584.2004.tb02722.x

Robinson T, McMullan G, Marchant R, Nigam P (2001) Remediation of dyes in textile 

Bioresour Technol. doi: 10.1016/S0960-8524(00)00080-8

Saha P Das, Chakraborty S, Chowdhury S (2012) Batch and continuous (fixed-bed column) biosorption of crystal violet by Artocarpus heterophyllus (jackfruit) leaf powder. Colloids Surfaces B Biointerfaces. doi: 10.1016/j.colsurfb.2011.11.057

Saini RD (2017) Textile Organic Dyes: Polluting effects and Elimination Methods from Textile Waste Water.

Seth S, Matzger AJ (2017) Metal-Organic Frameworks: Examples, Counterexamples, and an Actionable Definition. Cryst. Growth Des.

Tiwari MK, Bajpai S, Dewangan UK, Tamrakar RK (2015) Assessment of heavy metal concentrations in surface water sources in an industrial region of central India. Karbala Int J Mod Sci. doi: 10.1016/j.kijoms.2015.08.001

Vu TA, Le GH, Dao CD, et al (2015) Arsenic removal from aqueous solutions by adsorption using novel MIL-53(Fe) as a highly efficient adsorbent. RSC Adv. doi: $10.1039 / \mathrm{c} 4 \mathrm{ra} 12326 \mathrm{c}$

Wang J, Guo X (2020a) Adsorption kinetic models: Physical meanings, applications, and solving methods. J. Hazard. Mater. 390:

Wang J, Guo X (2020b) Adsorption isotherm models: Classification, physical meaning, application and solving method. Chemosphere 258:

Wang X, Guo Y, Jia Z, et al (2021) Fabrication of graphene oxide/polydopamine adsorptive membrane by stepwise in-situ growth for removal of rhodamine B from water. Desalination. doi: 10.1016/j.desal.2021.115220

Weber TW, Chakravorti RK (1974) Pore and solid diffusion models for fixed-bed adsorbers. AIChE J. doi: 10.1002/aic.690200204

Wu Q, Siddique MS, Guo Y, et al (2021) Low-crystalline bimetallic metal-organic frameworks as an excellent platform for photo-Fenton degradation of organic contaminants: Intensified synergism between hetero-metal nodes. Appl Catal B Environ. doi: 10.1016/j.apcatb.2021.119950

Yadav S, Tyagi DK (2011) Equilibrium and Kinetic Studies on Adsorption of Aniline Blue From Aqueous Solution Onto Rice Husk Carbon.

Yaghi OM, O’Keeffe M, Ockwig NW, et al (2003) Reticular synthesis and the design of new materials. Nature

Yan J, Jiang S, Ji S, et al (2015) Metal-organic framework MIL-53(Al): Synthesis, catalytic performance for the Friedel-Crafts acylation, and reaction mechanism. Sci China Chem. 
doi: 10.1007/s11426-015-5359-0

Zaheer Z, AL-Asfar A, Aazam ES (2019) Adsorption of methyl red on biogenic Ag@Fe nanocomposite adsorbent: Isotherms, kinetics and mechanisms. J Mol Liq. doi: 10.1016/j.molliq.2019.03.030

Zarenezhad M, Zarei M, Ebratkhahan M, Hosseinzadeh M (2021) Synthesis and study of functionalized magnetic graphene oxide for $\mathrm{Pb} 2+$ removal from wastewater. Environ Technol Innov. doi: 10.1016/j.eti.2021.101384

\section{Statements \& Declarations}

\section{Compliance with Ethical Standards}

Not applicable

\section{Consent to Participate}

Not applicable

\section{Consent to Publish}

Not applicable

\section{Funding}

All the author thanks the School of Environmental Science and Engineering and Central Research Facility at IIT, Kharagpur for the technical and material support, space and instrumentation to carry out this work. Also, H Singh, S Raj, and Dr. RKS Rathour sincerely appreciate the Ministry of Human Resource Development, Government of India, for their $\mathrm{PhD}$. Fellowships.

\section{Competing Interests}

The authors have no competing interests to declare that are relevant to the content of this article.

\section{Author Contributions}

All the authors' contribution has been acknowledged as mentioned. Hemant Singh: Conceptualization, Methodology, Software, Data curation, writing original-draft, 
751 visualization and Investigation. Sankalp Raj: Assistance to Investigation. Rishi Karan Singh

752 Rathour: Assistance to Investigation, Writing-review \& editing. Jayanta Bhattacharya:

753 Assistance to Investigation, Supervision, Writing-review \& editing.

754 Data Availability

755 All the relevant experimental data are within the manuscript.

756 